Al1203 074684

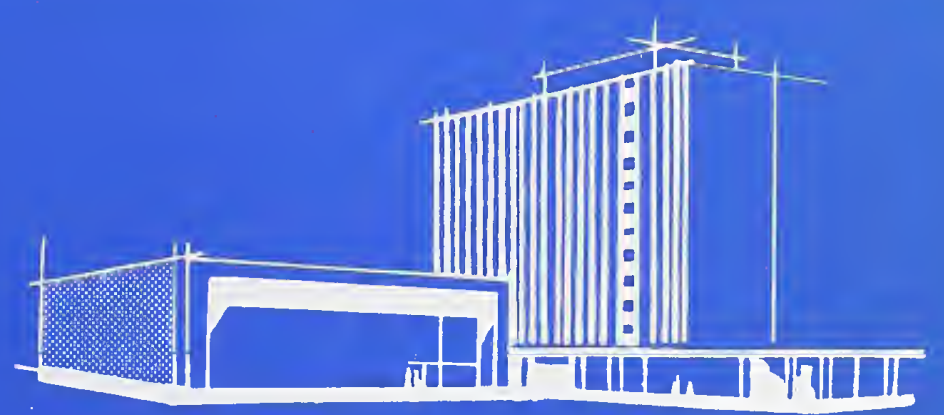

U.S. ARTMENT OF MMMERCE National Bureau of Standards

\title{
Compressive Strength of Slender Concrete Masonry Walls
}




\section{The Building Science Series}

The Building Science Series disseminates technical information developed at the National Bureau of Standards on building materials, components, systems, and whole structures. The Series presents research results, test methods, and performance criteria related to the structural and environmental functions and the durability and safety characteristics of building elements and systems.

These publications, similar in style and content to the NBS Building Materials and Structures Reports (1938-59), are directed toward the manufacturing, design, construction, and research segments of the building industry, standards organizations, and officials responsible for building codes.

The material for this Series originates principally in the Building Research Division of the NBS Institute for Applied Technology. The publications are divided into three general groups: Building Systems and Processes: Health, Safety, and Comfort: and Sturctures and Materials. Listed below are other publications in the category of -

\section{Structures and Materials}

- Interrelations Between Cement and Concrete Properties: Part 1, Materials and Techniques, Water Requirements and Trace Elements. (C13.29/2:2) 35 cents

- Weather Resistance of Porcelain Enamels: Effect of Exposure Site and Other Variables After Seven Years. (C13.29/2:4) 20 cents

- Interrelations Between Cement and Concrete Properties: Part 2, Sulfate Expansion, Heat of Hydration, and Autoclave Expansion. (C13.29/2:5) 35 cents

- Some Properties of the Calcium Aluminoferrite Hydrates. (C13.29/2:6) 20 Cents

- Organic Coatings, Properties, Selection, and Use. (C13.29/2:7) $\$ 2.50$

- Interrelations Between Cement and Concrete Properties: Part 3, Compressive Strengths of Portland Cement Test Mortars and Steam-Cured Mortars. (C13.29/2:8) 55 cents

- Thermal-Shock Resistance for Built-Lp Membranes (C.13.29/2:9) 20 cents

- Shrinkage and Creep in Prestressed Concrete. (C13.29/2:13) 15 cents

- Experimental Determination of Eccentricity of Floor Loads Applied to a Bearing Wall. (C13.29/2:14) 15 cents

- Interrelations Between Cement and Concrete Properties: Part 4, Shrinkage of Hardened Portland Cement Pastes. (C.13.29/2:15) 75 cents

- Causes of Variation in Chemical Analyses and Physical Tests of Portland Cement. (C13.29/2:17) 40 cents

- A Study of the Variables Involved in the Saturating of Roofing Felts. (C13.29/2:19) 30 cents

- Proceedings of a Seminar on the Durability of lnsulating Glass. (C13.29/2:20) 75 cents

- Hail Resistance of Roofing Products. (C13.29/2:23) 25 cents

- Natural Weathering of Mineral Stabilized Asphalt Coatings on Organic Felt. (C13.29/2:24) 30 cents

- Structural Performance Test of a Building System. (C13.29/2:25) \$1.25

- Exploratory Studies of Early Sirength Development in Portland Cement Pastes and Mortars. (C13.29/2:28) 25 cents

- 1964. Exposure Test of Porcelain Enamels on Aluminum-Three Year Inspection. (C13.29/2:29) 25 cents

- Flexural Behavior of Prestressed Concrete Composite Tee-Beams (C13.29/2:31) 25 cents

- Strength of Masunry Walls under Compressive and Transverse Loads (C13.29/2:34) In press

Send orders (use Superintendent of Documents Catalog Nos.) with remittance 10: Superintendent of Documents, U.S. Government Printing Office, Washington, D.C. Remittance from foreign countries should include an additional one-fourth of the purchase price for postage. 


\title{
Compressive Strength of Slender Concrete Masonry Walls
}

\author{
Felix Y. Yokel, Robert G. Mathey, and Robert D. Dikkers \\ Building Research Division \\ Institute for Applied 'Technology \\ National Bureau of Standards \\ Washington, D.C. 20234
}

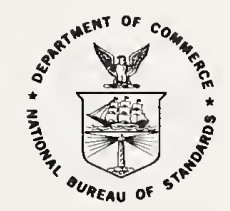

Building Science Series 33

Nat. Bur. Stand. (U.S.), Bldg. Sci. Ser. 33, 32 pages (Dec. 1970)

CODEN: BSSNB

Issued December 1970

For sale by the Superintendent of Documents, U.S. Government Printing Office, Washington, D.C. 20402 (Order by SD Catalog No. C13.29/2:33), Price 40 cents 
The contents of this report are not to be used for advertising or promotional purposes. Citation of proprietary products does not constitute an official endorsement or approval by the National Bureau of Standards for use of such commercial products. 


\section{Contents}

List of Symbols.

SI Conversion Units.

iv

Abstract

1. Introduction and Objective

1

2. Scope

3. Test Specimens

4. Test Procedure and Instrumentation.

5. Test Results

6. Interpretation of Results

7. Discussion of Present Design Procedures.

8. Conclusions and Recommendations

9. Acknowledgment

10. References. 


\section{List of Symbols}

a Flexural compressive strength coefficient

$a f_{m}^{\prime} \quad$ Flexural compressive strength of masonry

$C_{m} \quad$ Moment correction coefficient

$e \quad$ Eccentricity relative to centroid of section

$E \quad$ Modulus of elasticity

$E_{i} \quad$ Initial tangent modulus of elasticity

$E_{m} \quad$ Modulus of elasticity of masonry

$E_{s} \quad$ Modulus of elasticity of steel

$E_{t} \quad$ Tangent modulus of elasticity at failure

$f_{a} \quad$ Computed axial compressive stress

$F_{a} \quad$ Allowable axial compressive stress

$f_{m} \quad$ Computed flexural compressive stress

$F_{m} \quad$ Allowable flexural compressive stress

$f_{m}^{\prime}$

$h$

I

$I_{n}$

$k$

$M_{1}$

$M_{2}$

$P$

$P^{\prime}$

Prr determined from axial prism test

Unsupported height of wall

Moment of inertia of section

Moment of inertia based on uncracked net section

Reduction coefficient to account for end fixity $k h$

$M$

$n$

$P_{0}$

Unsupported height of wall reduced for enc fixity

Maximum moment acting on the wall

Larger end moment acting on the wall

Smaller end moment acting on the wall

Stiffness ratio of reinforcing steel to masonry

Applied vertical compressive load (or re. action to that load)

Cross-sectional axial compressive loac capacity

Resultant compressive force acting on cross section

Critical load for stability-induced com. pression failure computed on the basis of a modified EI, accounting for section cracking and reduced stiffness at maximum stress.

$t \quad$ Thickness of wall

$\delta \quad$ Transverse deflection

\section{SI Conversion Units}

In view of present accepted practice in this country in this technological area, common U.S. units of measurement have been used throughout this paper. In recognition of the position of the USA as a signatory to the General Conference on Weights and Measures, which gave official status to the metric SI systems of units in 1960, we assist readers interested in making use of the coherent system of SI units, by giving conversion factors applicable to U.S. units used in this paper.

Length

1 in $=0.0254 *$ meter

$\mathrm{l} \mathrm{ft}=0.3048^{*}$ meter

Area

1 in $^{2}=6.4516^{*} \times 10^{-4}$ meter $^{2}$

$1 \mathrm{ft}^{2}=0.09290$ meter $^{2}$

Force

$1 \mathrm{lb}(\mathrm{lbf})=4.448$ newton

1 kip $=4448$ newton
Pressure, Stress

$1 \mathrm{psi}=6895$ newton $/$ meter $^{2}$

$1 \mathrm{ksi}=6.895 \times 10^{6}$ newton $/$ meter $^{2}$

Mass/Volume

$1 \mathrm{lb} / \mathrm{ft}^{3}\left(1 \mathrm{bm} / \mathrm{ft}^{3}\right)=16.02$ kilogram $/$ meter $^{3}$

Moment

1 kip-in $=113.0$ newton-meter

*Exactly 


\title{
Compressive Strength of Slender Concrete Masonry Walls*
}

\author{
Felix Y. Yokel, Robert G. Mathey, and Robert D. Dikkers
}

\begin{abstract}
Sixty reinforced and unreinforced concrete masonry walls of different slenderness ratios were tested to failure under vertical loads applied axially and at various eccentricities. Prism specimens, made of similar masonry units and mortars, were also tested under the same loading conditions. Analysis of test results indicates that wall strength can be conservatively predicted by evaluating cross-sectional wall capacity on the basis of prism strength and reducing the capacity for slenderness effects by evaluating the added moments attributable to wall deflection. Test results were also compared with allowable loads computed in accordance with the current NCMA standard.
\end{abstract}

Key words: Buckling: compressive strength: concrete block walls: elastic stability; flexural strength: masonry walls: reinforced concrete masonry walls; slenderness effect; structural stability.

\section{Introduction and Objective}

At the present time only a limited amount of experimental data is available on the compressive strength of slender concrete masonry walls. Present design practice accounts for slenderness effects by stress correction factors $[1]^{1}$ or empirical equations [2]. The designer has no rational method by which he can evaluate slenderness effects, and important parameters such as cross-sectional properties, end support conditions. and the relationship between compressive strength and elastic properties of the masonry are not taken into consideration.

The objectives of this investigation were to determine and analyze the effects of wall slenderness and load eccentricity on the strength of slender concrete masonry walls. This analysis was intended to represent a step in the development of rational design methods for masonry walls subjected to axial and eccentric vertical loads.

\section{Scope}

Two wall systems representing reinforced and unreinforced masonry construction were tested:

1. 6-in reinforced concrete masonry walls.

2. 8-in unreinforced concrete masonry walls.

*This work was performed with the aid of a financial grant from the National Concrete Masonry Association (NCMA).

${ }^{1}$ Figures in brackets indicate literature references listed in section 10.
For each of these wall systems specimens were constructed which were 4 -ft wide and approximately 10 , 16, and 20 -ft high. ${ }^{2}$ These walls were tested to destruction under vertical loads which were applied axially and at eccentricities of $\frac{1}{6}, \frac{1}{4}$ and $\frac{1}{3}$ of the wall thickness.

For each combination of wall height and load eccentricity, two companion specimens were tested. One of these specimens was instrumented to measure horizontal deflections and wall shortening under vertical loads. All of these specimens were tested at an approximate age of ten days. In addition. two $10-\mathrm{ft}$ high and two $20-\mathrm{ft}$ high walls of each wall system were tested axially at an age of more than 28 days to determine the strength increase with an additional curing period.

Following construction, four of the unreinforced walls were found to have undersized block and increased joint thicknesses as a consequence. These specimens were tested, and an additional four specimens with correct joint size were added to provide unbiased data. As indicated in table 2.1, a total of 28 reinforced walls and 32 unreinforced walls were tested.

An investigation of masonry prism strength under eccentric compressive loads was also conducted by subjecting 8-in and 6-in masonry prisms to the same loading conditions that were used for the full scale

2 Hereafter in this report heights of walls are referred to as $10 \mathrm{ft}$, $16 \mathrm{ft}$ and $20 \mathrm{ft}$. However, actual wall heights were $9 \mathrm{ft}-3 \frac{5}{8} \mathrm{in}, 15 \mathrm{ft}$ $11 \frac{5}{8}$ in and $19 \mathrm{ft}-3 \frac{5}{8}$ in. 


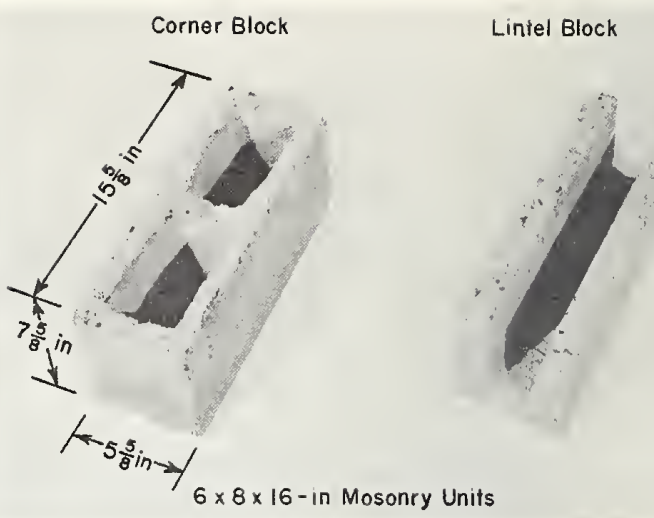

\begin{tabular}{c|c|cccc|c}
$\begin{array}{c}\text { Wal1 } \\
\text { System }\end{array}$ & $\begin{array}{c}\text { Wal1 } \\
\text { Height } \\
\mathrm{ft}\end{array}$ & \multicolumn{4}{|c|}{ Load Eccentricity } & $\begin{array}{c}\text { Number } \\
\text { of } \\
\text { Walls } \\
\text { Tested }\end{array}$ \\
\hline 6-in & 10 & 4 & 2 & 2 & 2 & 10 \\
reinforced & 16 & 2 & 2 & 2 & 2 & 8 \\
& 20 & 4 & 2 & 2 & 2 & 10 \\
\hline 8-in & 10 & 6 & 4 & 2 & 2 & 14 \\
unreinforced & 16 & 2 & 2 & 2 & 2 & 8 \\
& 20 & 4 & 2 & 2 & 2 & 10 \\
\hline
\end{tabular}

walls. Two-block high as well as three-block high prisms were tested in order to determine the effect of prism height on the prism strength.

The investigation was completed by an analysis of results which is presented in section 6 of this report, and a discussion of present design practice which is included in section 7 .

\section{Test Specimens}

\subsection{Materials}

\subsubsection{Masonry Units}

Concrete masonry units used in the construction of test specimens were $8 \times 8 \times 16$-in two-core hollow block, which were used in the unreinforced walls, and $6 \times 8 \times 16$-in two-core hollow block which were used in the reinforced walls.

The units were made of a blend of light and normal weight aggregate (cinder and limestone) and were autoclaved. Cementitious material was portland cement and silica flour. The specified compressive strength of the units, based on net cross-sectional area, was 3,000 psi. Actual average compres-

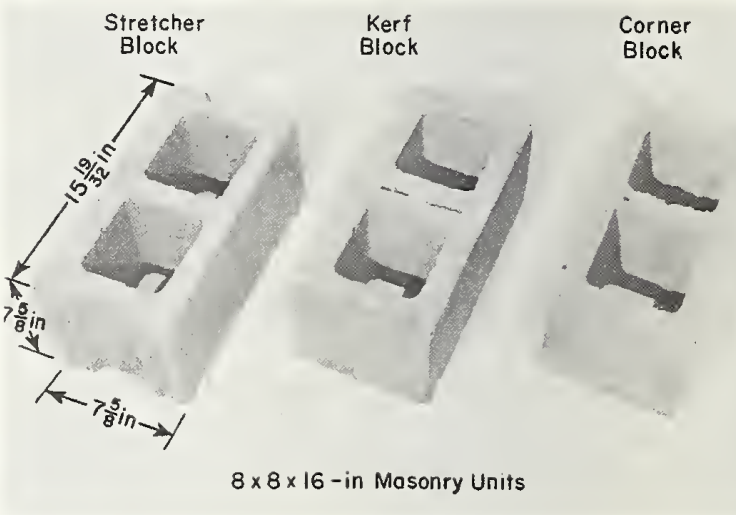

F1GURE 3.1. Masonry units.

sive strength of the units tested was 4230 psi and 4080 psi for the 8-in and the 6-in units, respectively.

The masonry units used are illustrated in figure 3.1. Dimensions and properties of the masonry units which were determined in accordance with ASTM standard C140-65T [3] are recorded in table 3.1.

\subsubsection{Mortar}

The mortar used in all wall panels was type $S$ mortar, in aceordance with the proportion specifications

TABLE 3.1 Dimensions and Properties of Concrete Masonry Units a/

\begin{tabular}{|c|c|c|c|c|c|c|c|c|c|c|c|c|}
\hline \multirow[t]{2}{*}{ Unit } & \multirow{2}{*}{$\begin{array}{r}\text { Width } \\
\text { in } \\
\end{array}$} & \multirow{2}{*}{$\begin{array}{c}\text { Height } \\
\text { in }\end{array}$} & \multirow{2}{*}{$\begin{array}{c}\text { Length } \\
\text { in } \\
\end{array}$} & \multicolumn{2}{|c|}{$\begin{array}{c}\text { Minimum } \\
\text { Thickness } \\
\text { in }\end{array}$} & \multirow{2}{*}{$\begin{array}{l}\text { Gross } \\
\text { Area } \\
\text { in }^{2} \\
\end{array}$} & \multirow{2}{*}{$\begin{array}{l}\text { Net } \\
\text { Area } \\
\\
\%\end{array}$} & \multicolumn{2}{|c|}{$\begin{array}{l}\text { Compressive } \\
\text { Strength }\end{array}$} & \multirow{2}{*}{$\begin{array}{c}\text { Oven } \\
\text { Dry } \\
\text { Weight } \\
1 \mathrm{~b} \\
\end{array}$} & \multirow{2}{*}{$\begin{array}{c}\text { Concrete } \\
\text { Weight } \\
1 \mathrm{~b} / \mathrm{ft}^{3}\end{array}$} & \multirow{2}{*}{$\begin{array}{c}\begin{array}{c}\text { Water } \\
\text { Absorption }\end{array} \\
1 \mathrm{~b} / \mathrm{ft}^{3}\end{array}$} \\
\hline & & & & $\begin{array}{l}\text { Face } \\
\text { Shell }\end{array}$ & Web & & & $\begin{array}{c}\text { Gross } \\
\text { Area } \\
\text { psi }\end{array}$ & $\begin{array}{l}\text { Net } \\
\text { Area } \\
\text { psi }\end{array}$ & & & \\
\hline $\begin{array}{l}\text { 8-in } \\
\text { block }\end{array}$ & $75 / 8$ & $75 / 8$ & $1519 / 32$ & $15 / 16$ & 1 & 118.90 & 52.33 & 2213 & 4230 & 29.71 & 108.20 & 11.32 \\
\hline $\begin{array}{l}\text { 6-in } \\
\text { block }\end{array}$ & $55 / 8$ & $75 / 8$ & $155 / 8$ & 1 & 1 & 87.89 & 55.89 & 2280 & 4080 & 22.78 & 105.09 & 12.21 \\
\hline
\end{tabular}

a/ Values given in the table represent the average results from tests or measurements of 5 units. 
of ASTM C270 [4]. Type I portland cement, masonry cement and sand were proportioned 1/2:1:4 by volume. The sand was bank run siliceous aggregate from White Marsh, Maryland, with a fineness modulus of 1.73 .

Forty-one sets of 2-in mortar cubes were made during the fabrication of the wall panels. The mortar cubes were made and stored under the same conditions as the wall panels. In general, the mortar cubes were tested at approximately the same age as the corresponding walls. However, some of the reinforced concrete masonry wall panels took 6 days to fabricate because of waiting time for two grouting operations and weekend delays. The age of tested mortar cubes, therefore, ranged from 7 to 53 days. Mortar cube strength averaged 1180 psi. Individual mortar cube tests are listed in table 3.2. As indicated in the table, the cube strengths ranged from 700 to 1768 psi. However, 30 of the 41 sets of cubes had compressive strengths within $300 \mathrm{psi}$ of the average value.
Since many batehes of mortar were used in the construction of a wall panel and many of the walls took up to 6 days to fabricate, the mortar strength varied in different elevations of the wall. The average mortar strength was 1180 psi.

\subsubsection{Grout}

The grout used in the reinforced concrete masonry wall panels was a coarse grout in accordance with ASTM C476 [5]. The grout mix had the following proportions by weight:

$\begin{array}{lr}\text { Type I Portland Cement } & 47 \mathrm{lb} \\ \text { Sand } & 120 \mathrm{lb} \\ \text { Gravel } & 80 \mathrm{lb} \\ \text { Water } & 40 \mathrm{lb}\end{array}$

Proportions of portland cement, sand and gravel by volume were $1: 3: 2$.

The bank-run sand and gravel were siliceous aggregates. The sand had a fineness modulus of 1.73 . The gravel had a maximum size of $\frac{3}{8} \mathrm{in}$.

\begin{tabular}{|c|c|c|c|c|}
\hline No. Test & $\begin{array}{l}\text { Date of } \\
\text { Fabrication }\end{array}$ & $\begin{array}{l}\text { Date of } \\
\text { Test }\end{array}$ & $\begin{array}{l}\text { Age } \\
\text { days }\end{array}$ & $\begin{array}{c}\text { Average } \\
\text { Compress ive } \\
\text { Strength } \\
\text { psi }\end{array}$ \\
\hline $\begin{array}{l}1 \\
2 \\
3 \\
4 \\
5\end{array}$ & $\begin{array}{l}6 / 27 \\
6 / 28 \\
7 / 1 \\
8 / 26 \\
7 / 3\end{array}$ & $\begin{array}{l}7 / 15 \\
7 / 15 \\
7 / 15 \\
9 / 10 \\
7 / 23\end{array}$ & $\begin{array}{l}18 \\
17 \\
14 \\
15 \\
20\end{array}$ & $\begin{array}{r}758 \\
1166 \\
1282 \\
1271 \\
950\end{array}$ \\
\hline $\begin{array}{r}6 \\
7 \\
8 \\
9 \\
10\end{array}$ & $\begin{array}{l}7 / 5 \\
7 / 8 \\
7 / 9 \\
7 / 11 \\
7 / 10\end{array}$ & $\begin{array}{l}7 / 23 \\
7 / 23 \\
7 / 23 \\
7 / 29 \\
7 / 29\end{array}$ & $\begin{array}{l}18 \\
15 \\
14 \\
18 \\
19\end{array}$ & $\begin{array}{r}1250 \\
1006 \\
1125 \\
862 \\
1768\end{array}$ \\
\hline $\begin{array}{l}11 \\
12 \\
13 \\
14 \\
15\end{array}$ & $\begin{array}{l}7 / 12 \\
7 / 16 \\
7 / 16 \\
7 / 30 \\
7 / 31\end{array}$ & $\begin{array}{l}7 / 29 \\
8 / 14 \\
8 / 14 \\
8 / 20 \\
8 / 20\end{array}$ & $\begin{array}{l}17 \\
29 \\
29 \\
21 \\
20\end{array}$ & $\begin{array}{l}1317 \\
1139 \\
1000 \\
1309 \\
1125\end{array}$ \\
\hline $\begin{array}{l}16 \\
17 \\
18 \\
19 \\
20\end{array}$ & $\begin{array}{l}8 / 2 \\
8 / 6 \\
8 / 8 \\
7 / 9 \\
7 / 1\end{array}$ & $\begin{array}{l}8 / 20 \\
8 / 20 \\
8 / 21 \\
7 / 18 \\
7 / 16\end{array}$ & $\begin{array}{r}18 \\
14 \\
13 \\
9 \\
15\end{array}$ & $\begin{array}{l}1500 \\
1340 \\
1175 \\
1123 \\
1244\end{array}$ \\
\hline $\begin{array}{l}21 \\
22 \\
23 \\
24 \\
25\end{array}$ & $\begin{array}{l}7 / 2 \\
10 / 7 \\
10 / 7 \\
9 / 20 \\
9 / 6\end{array}$ & $\begin{array}{l}7 / 16 \\
11 / 4 \\
10 / 14 \\
10 / 2 \\
9 / 26\end{array}$ & $\begin{array}{r}14 \\
28 \\
7 \\
12 \\
20\end{array}$ & $\begin{array}{r}1286 \\
1628 \\
967 \\
1651 \\
1438\end{array}$ \\
\hline $\begin{array}{l}26 \\
27 \\
28 \\
29 \\
30\end{array}$ & $\begin{array}{l}9 / 10 \\
9 / 13 \\
9 / 16 \\
9 / 17 \\
8 / 22\end{array}$ & $\begin{array}{l}9 / 26 \\
9 / 27 \\
9 / 27 \\
9 / 27 \\
9 / 18\end{array}$ & $\begin{array}{l}16 \\
14 \\
11 \\
10 \\
27\end{array}$ & $\begin{array}{r}915 \\
1050 \\
1414 \\
1187 \\
700\end{array}$ \\
\hline $\begin{array}{l}31 \\
32 \\
33 \\
34 \\
35\end{array}$ & $\begin{array}{l}8 / 27 \\
8 / 29 \\
9 / 3 \\
7 / 19 \\
7 / 22\end{array}$ & $\begin{array}{l}9 / 18 \\
9 / 18 \\
9 / 18 \\
9 / 10 \\
9 / 10\end{array}$ & $\begin{array}{l}22 \\
20 \\
15 \\
53 \\
50\end{array}$ & $\begin{array}{r}1267 \\
736 \\
1428 \\
1208 \\
1033\end{array}$ \\
\hline $\begin{array}{l}36 \\
37 \\
38 \\
39 \\
40 \\
41\end{array}$ & $\begin{array}{l}7 / 24 \\
7 / 26 \\
8 / 14 \\
9 / 18 \\
9 / 18 \\
9 / 19\end{array}$ & $\begin{array}{l}9 / 10 \\
9 / 10 \\
9 / 10 \\
9 / 30 \\
9 / 30 \\
9 / 30\end{array}$ & $\begin{array}{l}48 \\
46 \\
27 \\
12 \\
12 \\
11 \text { Average }\end{array}$ & $\begin{array}{r}1149 \\
1386 \\
794 \\
1354 \\
1356 \\
769 \\
1180\end{array}$ \\
\hline
\end{tabular}




\begin{tabular}{|c|c|c|c|c|c|c|}
\hline No. Test & $\begin{array}{c}\text { Date of } \\
\text { Fabrication }\end{array}$ & $\begin{array}{l}\text { Date of } \\
\text { Test }\end{array}$ & $\begin{array}{l}\text { Age } \\
\text { days }\end{array}$ & $\begin{array}{c}\text { Wal1 } \\
\text { Designation }\end{array}$ & $\begin{array}{l}\text { Pane1 } \\
\text { No. }\end{array}$ & $\begin{array}{c}\text { Compressive } \\
\text { Strength } \\
\text { psi }\end{array}$ \\
\hline 1 & $7 / 24$ & $9 / 9$ & 47 & $\begin{array}{l}20-R-0 \\
20-R-0\end{array}$ & $\begin{array}{l}1 \\
2\end{array}$ & 2476 \\
\hline 2 & $7 / 26$ & $9 / 9$ & 45 & $\begin{array}{l}20-R-0 \\
20-R-0\end{array}$ & $\begin{array}{l}1 \\
2\end{array}$ & 2264 \\
\hline 3 & $7 / 10$ & $7 / 23$ & 13 & $\begin{array}{l}16-R-T 4 \\
16-R-T 4\end{array}$ & $\begin{array}{l}5 \\
6\end{array}$ & 1910 \\
\hline 4 & $7 / 15$ & $7 / 26$ & 11 & $\begin{array}{l}\text { 16-R-T4 } \\
\text { 16-R-T4 }\end{array}$ & $\begin{array}{l}5 \\
6\end{array}$ & 2009 \\
\hline 5 & $8 / 2$ & $8 / 17$ & 15 & $\begin{array}{l}16-R-T 3 \\
16-R-T 3\end{array}$ & $\begin{array}{l}7 \\
8\end{array}$ & 2193 \\
\hline 6 & $7 / 10$ & $7 / 18$ & 8 & $\begin{array}{l}16-R-T 6 \\
16-R-T 6\end{array}$ & $\begin{array}{l}3 \\
4\end{array}$ & 1857 \\
\hline 7 & $8 / 19-8 / 30$ & $9 / 27$ & $28-39$ & & & 2228 \\
\hline 8 & $8 / 19-8 / 30$ & $9 / 27$ & $28-39$ & & & 2900 \\
\hline 9 & $8 / 19-8 / 30$ & $9 / 27$ & $28-39$ & & & 2387 \\
\hline 10 & $8 / 19-8 / 30$ & $9 / 27$ & $28-39$ & & & 2546 \\
\hline \multirow[t]{2}{*}{11} & $9 / 6$ & $9 / 27$ & 21 & $\begin{array}{l}20-R-T 4 \\
20-R-T 4\end{array}$ & $\begin{array}{l}7 \\
8\end{array}$ & 2449 \\
\hline & & & & & Average & 2290 \\
\hline
\end{tabular}

Eleven $6 \times 12$-in grout cylinders were made during the fabrication of the reinforced masonry walls, and cured under similar conditions as the walls. The compressive strengths ranged from 1857 psi to 2900 psi and averaged 2290 psi when tested at ages from 8 to 47 days. Individual test results are tabulated in table 3.3. It was observed that in general the strengths increased with an increase in age of the grout cylinder. The cylinders tested at the least age, 8 days, gave the lowest compressive strength. Since the test results indicated that the majority of the cylinders, a total of 8 , had compressive strengths within 300 psi of the average value, the average value of compressive strength can be assumed to be a representative value for all the grout cylinders.

It has been observed [6] that because of the water absorption by the masonry units, grout witlin the walls achieves a significantly higher strength than the same grout when cured as cylinders. It may therefore be assumed that the grout within the walls had a compressive strength higher than the 2290 psi cylinder strength.

\subsubsection{Steel Reinforcement}

Vertical and horizontal steel in the reinforced wall panels consisted of ASTM A615 [7] No. 5 deformed bars with a minimum specified yield strength of $60,000 \mathrm{psi}$.

\subsection{Construction of Specimens}

\subsubsection{General}

The wall panels and prisms were built and cured in the laboratory at approximately $73^{\circ} \mathrm{F}$ and 50 percent relative humidity. Wall panels were constructed in pairs between wooden guides to assure proper alignment and plumbness. Joint thickness was controlled at $\frac{3}{8}$ in by horizontal lines at 16 -in intervals which correspond to the height of two blocks and two joints. This method led to oversized joints in four unreinforced panels, where block which were undersized in height were used.

\subsubsection{6-in Reinforced Walls}

Wall panels were constructed in three nominal sizes: $4 \times 10-\mathrm{ft}, 4 \times 16-\mathrm{ft}$ and $4 \times 20-\mathrm{ft}$. Walls were built of the $6 \times 8 \times 16$-in concrete block which were laid in running bond.

A wall cross section is shown in figure 3.2(a). Faceshell bedding was used for the horizontal and vertical mortar joints. and mortar was also placed on the cross webs around the cores which were to be grouted. The mortar joint thickness was $\frac{3}{8}$ in. One No. 5 bar was grouted into each of the two outside cores of the wall as shown in figure 3.2(a). Vertical bars in the 16- and the 20 -ft walls were spliced near 


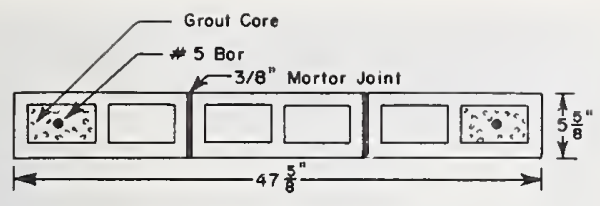

(a.) Typical Horizontal Section
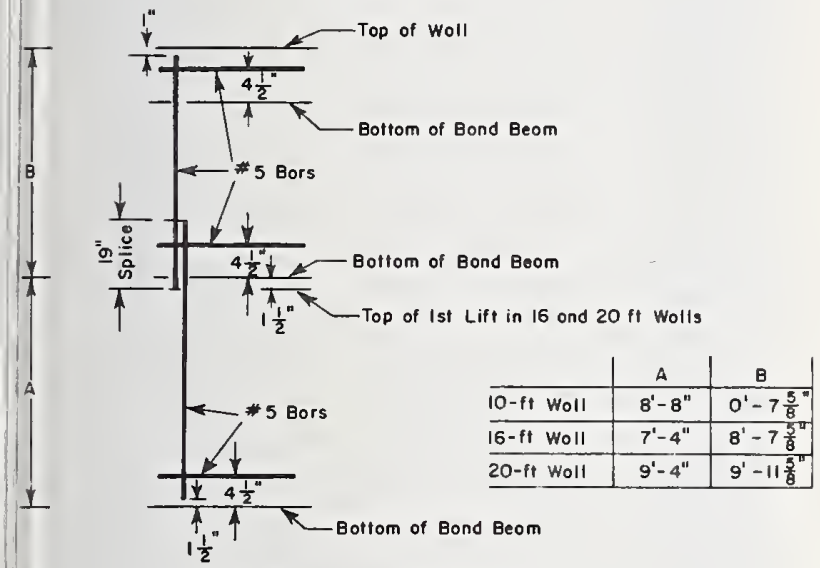

(b) Reinforcement Details

FiguRE 3.2. 6-in reinforced walls

midheight over a length of 30 bar diameters (19 in). Horizontal reinforcement consisting of one No. 5 deformed bar was installed in each bond beam as shown in figure $3.2(\mathrm{~b})$. These bars were grouted into $6 \times 8 \times 16$-in lintel block laid horizontally. The 10 -ft walls had bond beams at the top and bottom course. whereas the 16- and $20-\mathrm{ft}$ walls had an additional bond beam at midheight. The actual cross-sectional dimensions of the walls were $47 \frac{5}{8}$ in by $5 \frac{5}{8} \mathrm{in}$; actual panel heights were $9 \mathrm{ft}-3 \frac{5}{8} \mathrm{in}, 15 \mathrm{ft}-11 \frac{5}{8} \mathrm{in}$, and 19 $\mathrm{ft}-3 \frac{5}{8} \mathrm{in}$.

Present design practice [2] specifies an area of steel not less than 0.0013 times the cross-sectional area of the wall in one direction and not less than 0.0007 in the other direction. The area of vertical steel used in the reinforced walls of this investigation was equal to 0.0023 times the cross-sectional area. The area of principal reinforcement was, therefore, about twice the minimum area required. The area of horizontal reinforcement varied from 0.0007 times the cross-sectional area for the $20-\mathrm{ft}$ walls to 0.001 times the cross-sectional area for the $10-\mathrm{ft}$ walls.

The reinforced walls were constructed in the following manner: The first course of each wall consisted of three whole lintel units (see fig. 3.l) which were laid on a full mortar bed on a plastic sheet placed on the laboratory floor. These units formed a horizontal trough into which the horizontal reinforcement could be grouted. A strip of painted $2.5 \mathrm{lb} / \mathrm{yd}^{2}$ diamond-mesh metal lath was placed over the top of these lintel units in the middle 32 -in of the wall to contain the grout. Wall construction was then continued to the bottom of the next bond beam course.

After completion of every three courses of block. mortar protrusions were removed from the two end cores by a 2 -ft long stick, to keep these cores clean for grouting. Clean-out holes were provided at each end of the bond beam. Sand was placed at the bottom of the vertical cores to be grouted to facilitate removal of the mortar droppings. Before grouting, the end cores and the bond beam were inspected and cleaned by compressed air.

Horizontal and vertical reinforcement bars were then placed and tied together, to prevent dislocation of the bars during grouting. Prior to grouting, the clean-out holes were covered by boards.

Walls were at least 16 hours old before grouting. In the first few walls, grout was consolidated by rodding. Subsequently, a vibrator was used to insure filling of voids, particularly in the bond beams. Grout was poured to within one inch from the top of the lift and reconsolidated after 30 minutes to remove air voids caused by water absorption by the masonry units. The grout in the first lift was permitted to set overnight before construction of the second half of the wall was started. The second half of the $16-\mathrm{ft}$ walls contained two bond beams which had only two lintel blocks. At the outer end of these beams regular half-block were used. Openings were cut into these half-block to accommodate the horizontal bar and to provide cleanout holes at mid height. In the $20-\mathrm{ft}$ walls all bond beams were built of three whole lintel block. The upper bond beam of the 10 -ft walls also consisted of three whole lintel units. The $10-\mathrm{ft}$ walls were constructed in one lift. Two lifts were used in the 16- and $20-\mathrm{ft}$ walls.

\subsubsection{8-in Unreinforced Walls}

Wall panels, as in the case of the reinforced walls, were constructed in nominal sizes of $4 \times 10 \mathrm{ft} .4 \times 16$ $\mathrm{ft}$ and $4 \times 20 \mathrm{ft}$, built in running bond with $8 \times 8 \times 16$ in masonry units. Face shell bedding was used for the horizontal and vertical joints and additional mortar was placed on the cross webs at the two wall ends. Mortar-joint thickness was $\frac{3}{8}$ in. Actual crosssectional dimensions of the walls were $47 \frac{5}{8}$ in $\times 7 \frac{5}{8}$ in. Actual wall heights were $9 \mathrm{ft}-3 \frac{5}{8} \mathrm{in} .15 \mathrm{ft}-11 \frac{5}{8}$ in and $19 \mathrm{ft}-3 \frac{5}{8}$ in. 


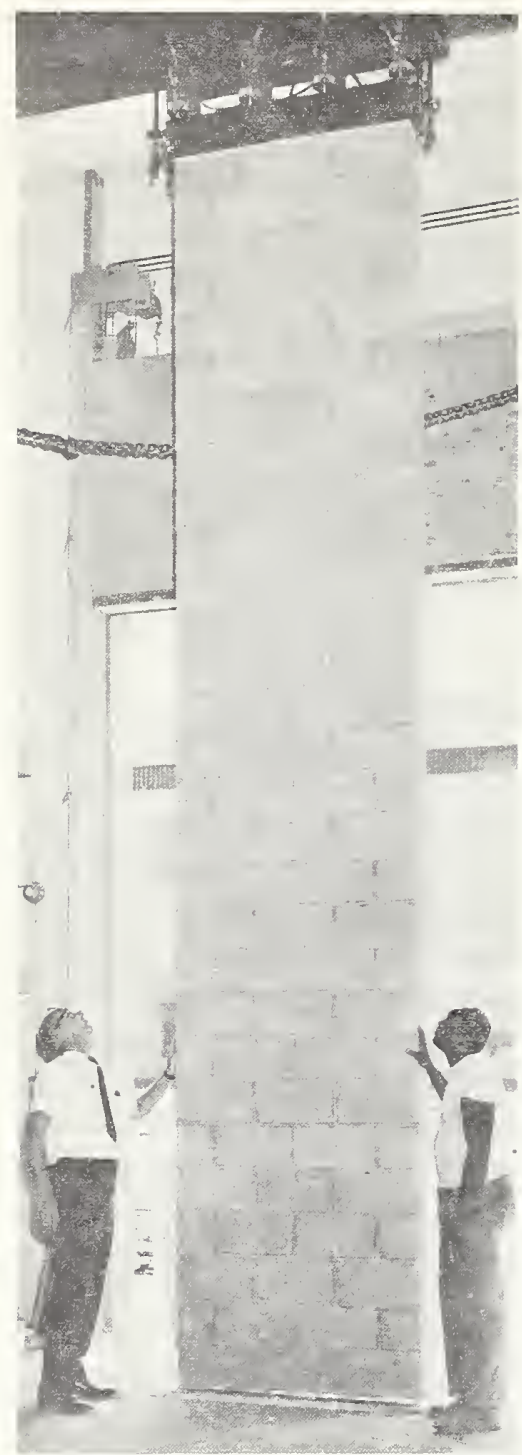

FIGURE 3.3. 20-ft high 8-in unreinforced wall panel.

The first course was constructed from three whole masonry units. Each alternate course contained two half-block at the wall ends. Kerf block were used as half-block, and corner block were used where whole units were required at the wall ends (refer to fig. 3.1). A typical 20-ft high wall panel is shown in figure 3.3 .

\subsubsection{Prism Specimens}

Prism specimens were built in stacked bond (one block wide) using the $8 \times 8 \times 16$-in block and the $6 \times$ $8 \times 16$-in block. Mortar was applied in face shell bedding as in the walls with $\frac{3}{8}$-in thick mortar joints. Three-block high as well as two-block high specimens were constructed.

Prisms were built at random during construction of the walls, using the same mortar batches, and

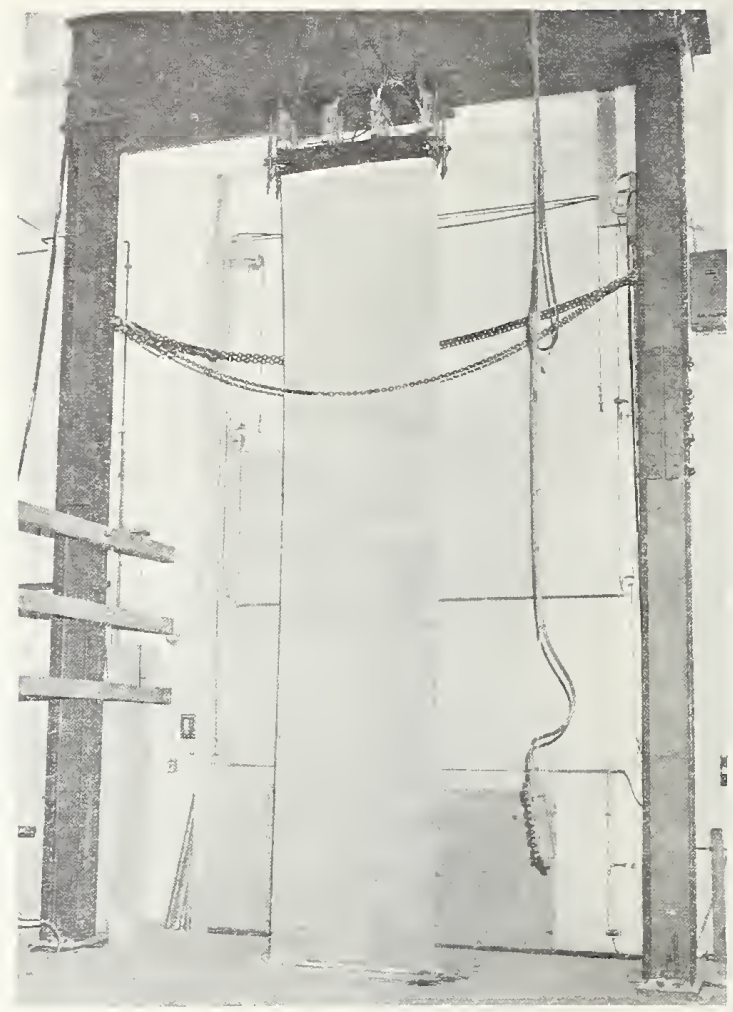

FiguRE 4.1. Loading system and frame.

cured under the same conditions as the walls. Befor testing, prisms were capped with high-strength plaster.

\section{Test Procedure and Instrumentation}

Wall panels were tested in a steel frame with an adjustable top cross-beam that could be raised of lowered to accommodate the various wall heights: Eight 30-ton capacity hydraulic rams were attached to the cross-beam. Figure 4.1 shows the loading system and the frame with a 20 -ft wall in place.

Figure 4.2 shows a diagram of the test setup. At the base a 1-in thick steel plate was cemented to the laboratory floor by high-strength plaster. The wall panel was set on top of this plate on another bed of high-strength plaster. When the wall was set, care! was taken to assure wall plumbness and alignment. Another 1-in thick steel plate was cemented to the top of the wall, to prevent wall failure by stress concentration. A $4 \frac{1}{2}$-in diameter steel half-round was set on this steel plate with the flat side toward the wall. The load was applied to the curved top of this steel half-round through a 4-in thick steel plate which 


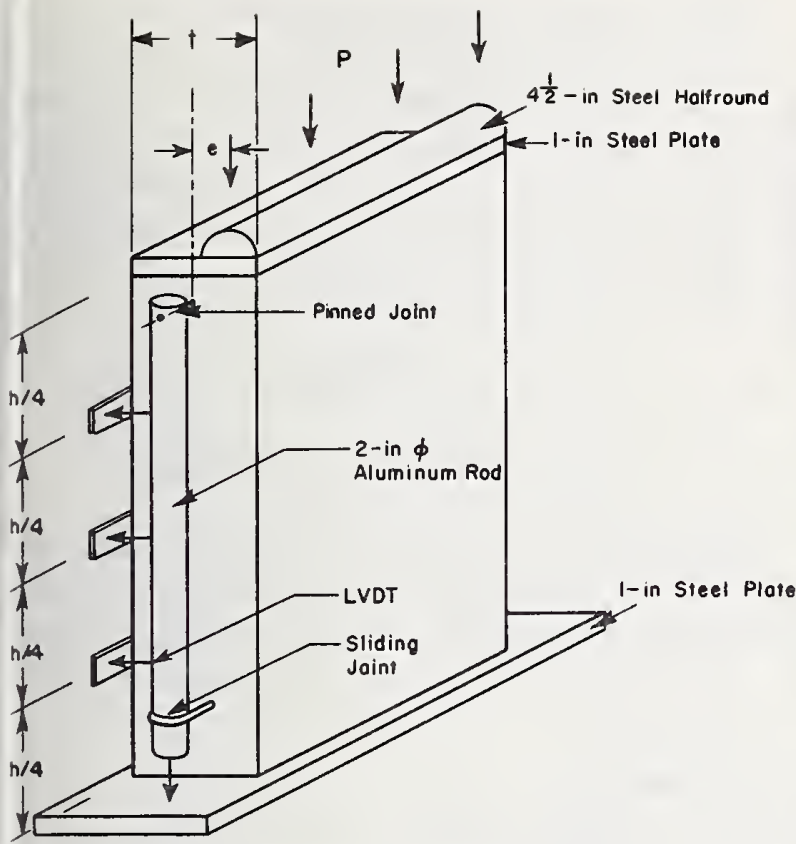

Figure 4.2. Test setup.

transmitted the load from the eight symmetricallylocated hydraulic rams. The loading head is shown in figure 4.3. The test setup described above was designed to prevent rotation at the base of the wall, while permitting free rotation at the top. Sidesway of the top of the wall was minimized by tying the loading frame to the laboratory wall at a height of $23 \mathrm{ft}$ above the floor level. Great care was taken to position the wall and the steel half-round precisely in order to apply the load at the desired eccentricity. Wall instrumentation is also illustrated schematically in figure 4.2. Aluminum tubes of 2 -in diameter were attached to the sides of the walls. At the upper end these tubes had a pinned connection to the wall and at the lower end they were attached to a guide which kept the tubes in line with the centerline of the wall but permitted them to slide downwards as the wall contracted under the load. For the first four 16-ft reinforced wall specimens, aluminum tubing of l-in diameter was used. It was observed, however, that this tubing tended to deflect slightly, and 2 -in diameter tubes were used in subsequent tests.

All instruments for the measurement of deflections were attached to these aluminum tubes. Horizontal deflections and wall shortenings were measured by linear variable differential transformers (LVDT's), capable of reading 0.0001 in. Instrument readings were electronically scanned at every $20 \mathrm{kip}$ increment of vertical load and recorded in digital form. These data were manually key punched onto cards and automatically reduced, analyzed and

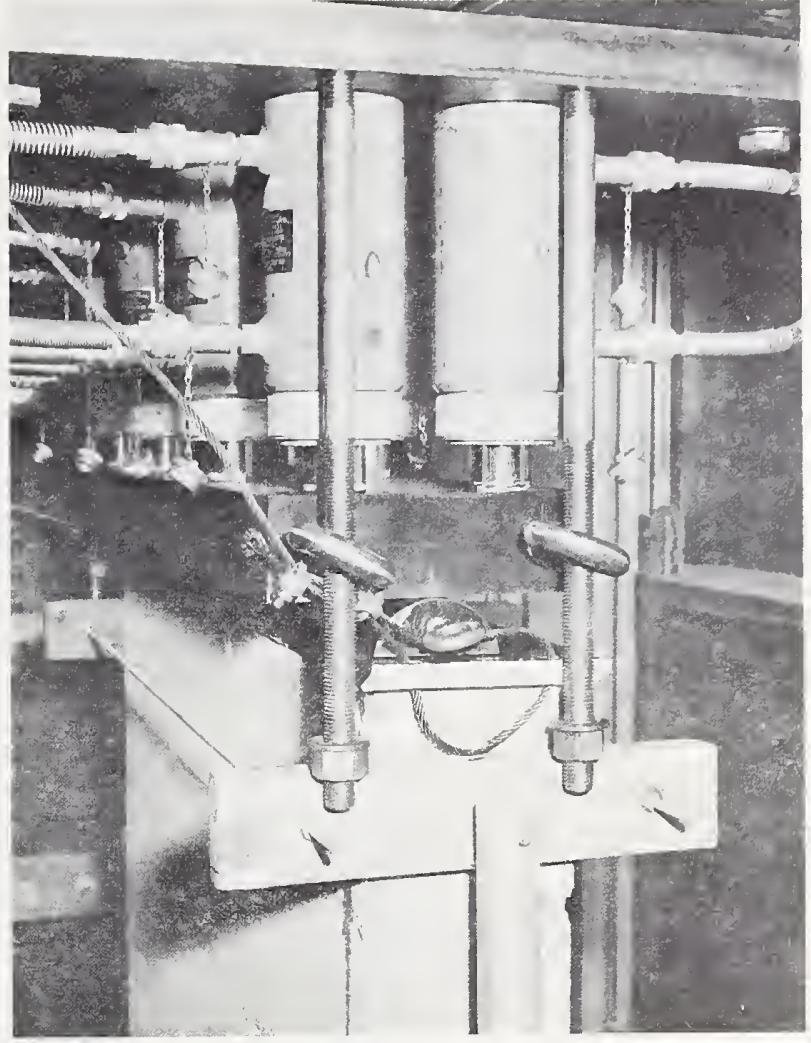

FlGURE 4.3. Loading head.

plotted by computer. Computer output consisted of tabulated test results and plotted load-deflection curves.

Instruments were installed to measure wall shortening and horizontal deflections at $\frac{1}{4}$-height. midheight and $\frac{3}{4}$-height of the wall. The instruments were installed symmetrically at both wall ends.

One 10-ft unreinforced wall was also instrumented over a 24-in gagc length on each wall face to determine the modulus of elasticity of the masonry.

Tests were carried out in duplicate for the same wall height and eccentricity. The first of the two walls tested was not instrumented and only failure load was recorded. The second specimen was instrumented, but the instrumentation was removed at about $\frac{2}{3}$ of the failure load of the first specimen. Deflection readings at wall failure are therefore not a vailable. This procedure was adopted to protect the instrumentation from damage by explosive wall failures.

The walls were moved from the fabrication area to the test frame by a fork lift truck. Before moving, the walls were carefully braced to prevent damage to the specimen. A wall being moved by the fork lift truck is shown in figure 4.4. 


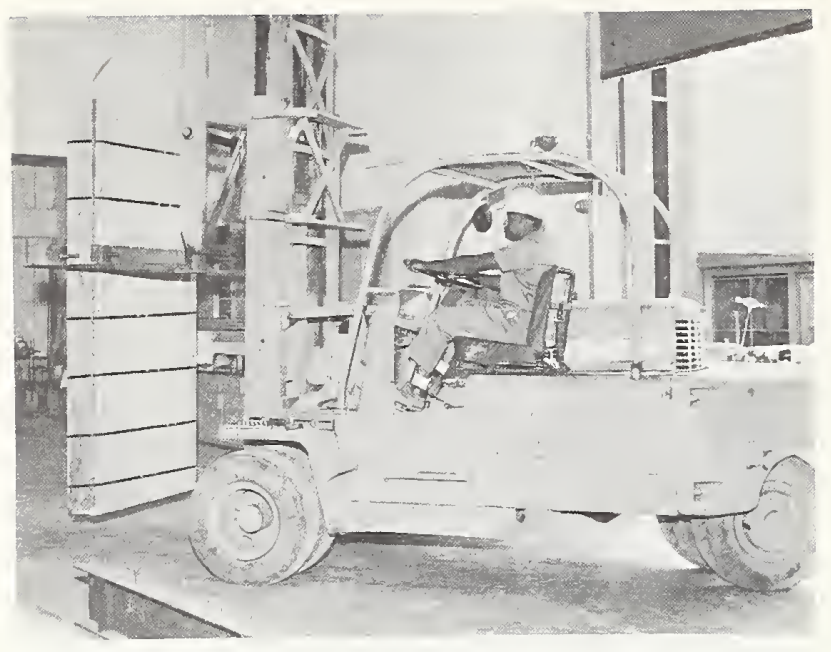

FIGURE 4.4. Wall being moved to the test frame.
Prism specimens were tested in the same manner as the wall panels. The prisms were set in highstrength plaster on a steel plate. A 1-in steel plate was set in plaster on top of the prisms, and load was applied'by a $4 \frac{1}{2}$-in steel half-round. Three-block high. as well as two-block high prisms were tested in duplicate for each load eccentricity.

\section{Test Results}

\subsection{6-in Reinforced Walls}

Results of tests on the 6-in reinforced walls are presented in table 5.1 and plotted in figure 5.1. Loaddeflection curves for these walls are shown in figures 5.2 through 5.4. The curves show horizontal deflec-

TABLE 5.1 Summary of 6-in Wa11 Test Results

\begin{tabular}{|c|c|c|c|c|c|}
\hline \multicolumn{2}{|c|}{$\begin{array}{l}\text { Wall Specimen } \\
\text { Designation }\end{array}$} & $\begin{array}{l}\text { Age } \\
\text { days }\end{array}$ & \multicolumn{2}{|c|}{$\begin{array}{c}\text { Eccentricity } \\
\text { in }\end{array}$} & $\underset{\text { Kip }}{\text { Ultimate Load }}$ \\
\hline $\begin{array}{l}10-R-0 \\
10-R-0 \\
10-R-0 \\
10-R-0\end{array}$ & $\begin{array}{l}1 \\
2 \\
3 \\
4\end{array}$ & $\begin{array}{l}30-32 \\
29-31 \\
11-12 \\
14-15\end{array}$ & $\begin{array}{l}0 \\
0 \\
0 \\
0\end{array}$ & $\begin{array}{l}0 \\
0 \\
0 \\
0\end{array}$ & $\begin{array}{l}354.8 \\
328.0 \\
361.8 \\
369.4\end{array}$ \\
\hline $\begin{array}{l}10-R-T 6 \\
10-R-T 6=\end{array}$ & $\begin{array}{l}5 \\
6\end{array}$ & $\begin{array}{l}15-16 \\
15-16\end{array}$ & $\begin{array}{l}t / 6 \\
t / 6\end{array}$ & $\begin{array}{l}0.94 \\
0.94\end{array}$ & $\begin{array}{l}296.2 \\
263.4\end{array}$ \\
\hline $\begin{array}{l}10-R-T 4 \\
10-R-T 4\end{array}$ & $\begin{array}{l}7 \\
8\end{array}$ & $\begin{array}{l}14-18 \\
14-18\end{array}$ & $\begin{array}{l}t / 4 \\
t / 4\end{array}$ & $\begin{array}{l}1.41 \\
1.41\end{array}$ & $\begin{array}{l}247.3 \\
236.6\end{array}$ \\
\hline $\begin{array}{l}10-R-T 3 \\
10-R-T 3\end{array}$ & $\begin{array}{r}9 \\
10\end{array}$ & $\begin{array}{l}14-15 \\
14-15\end{array}$ & $\begin{array}{l}t / 3 \\
t / 3\end{array}$ & $\begin{array}{l}1.88 \\
1.88\end{array}$ & $\begin{array}{l}189.8 \\
185.5\end{array}$ \\
\hline $\begin{array}{l}16-R-0 \\
16-R-0\end{array}$ & $\begin{array}{l}1 \\
2\end{array}$ & $\begin{array}{l}10-16 \\
11-17\end{array}$ & $\begin{array}{l}0 \\
0\end{array}$ & $\begin{array}{l}0 \\
0\end{array}$ & $\begin{array}{l}274.7 \\
281.2\end{array}$ \\
\hline $\begin{array}{l}16-R-T 6 \\
16-R-T 6\end{array}$ & $\begin{array}{l}3 \\
4\end{array}$ & $\begin{array}{r}7-13 \\
11-17\end{array}$ & $\begin{array}{l}t / 6 \\
t / 6\end{array}$ & $\begin{array}{l}0.94 \\
0.94\end{array}$ & $\begin{array}{l}212.9 \\
201.6\end{array}$ \\
\hline $\begin{array}{l}16-R-T 4 \\
16-R-T 4\end{array}$ & $\begin{array}{l}5 \\
6\end{array}$ & $\begin{array}{l}8-14 \\
9-15\end{array}$ & $\begin{array}{l}t / 4 \\
t / 4\end{array}$ & $\begin{array}{l}1.41 \\
1.41\end{array}$ & $\begin{array}{l}170.4 \\
190.9\end{array}$ \\
\hline $\begin{array}{l}16-R-T 3 \\
16-R-T 3\end{array}$ & $\begin{array}{l}7 \\
8\end{array}$ & $\begin{array}{l}7-9 \\
8-10\end{array}$ & $\begin{array}{l}t / 3 \\
t / 3\end{array}$ & $\begin{array}{l}1.88 \\
1.88\end{array}$ & $\begin{array}{l}146.8 \\
153.2\end{array}$ \\
\hline $\begin{array}{l}20-R-0 \\
20-R-0 \\
20-R-0 \\
20-R-0 \text { b }\end{array}$ & $\begin{array}{l}1 \\
2 \\
5 \\
6\end{array}$ & $\begin{array}{r}45-49 \\
45-49 \\
12-18 \\
7-13\end{array}$ & $\begin{array}{l}0 \\
0 \\
0 \\
0\end{array}$ & $\begin{array}{l}0 \\
0 \\
0 \\
0\end{array}$ & $\begin{array}{l}343.2 \\
331.7 \\
253.8 \\
184.4\end{array}$ \\
\hline $\begin{array}{l}20-R-T 6 \\
20-R-T 6\end{array}$ & $\begin{array}{l}3 \\
4\end{array}$ & $\begin{array}{l}19-21 \\
19-21\end{array}$ & $\begin{array}{l}t / 6 \\
t / 6\end{array}$ & $\begin{array}{l}0.94 \\
0.94\end{array}$ & $\begin{array}{l}198.4 \\
202.0\end{array}$ \\
\hline $\begin{array}{l}20-R-T 4 \\
20-R-T 4\end{array}$ & $\begin{array}{l}7 \\
8\end{array}$ & $\begin{array}{l}8-19 \\
9-20\end{array}$ & $\begin{array}{l}t / 4 \\
t / 4\end{array}$ & $\begin{array}{l}1.41 \\
1.41\end{array}$ & $\begin{array}{l}119.4 \\
129.0\end{array}$ \\
\hline $\begin{array}{l}20-R-T 3 \\
20-R-T 3\end{array}$ & $\begin{array}{r}9 \\
10\end{array}$ & $\begin{array}{r}9-13 \\
10-14\end{array}$ & $\begin{array}{l}t / 3 \\
t / 3\end{array}$ & $\begin{array}{l}1.88 \\
1.88\end{array}$ & $\begin{array}{l}73.5 \\
83.9\end{array}$ \\
\hline
\end{tabular}

a) Bottom lintel block cracked during fabrication.

b/ Wall had a broken block on one end of the 8th course from the top. 


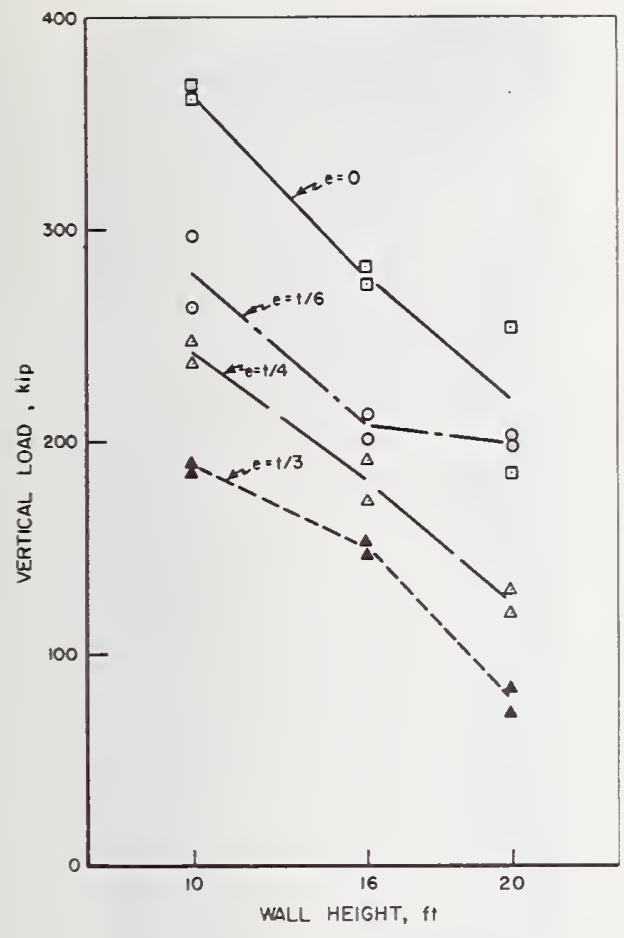

FiclRE 5.1. Failure loads for 6-in reinforced walls.

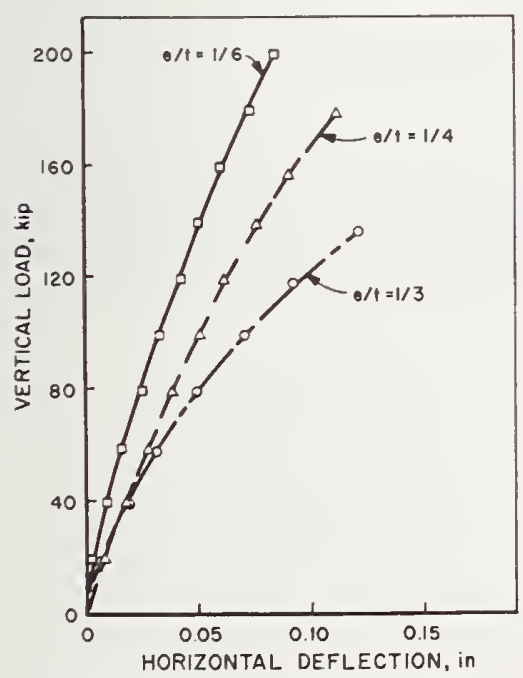

Figure 5.2. Load-deflection curves for 10-ft reinforced walls.

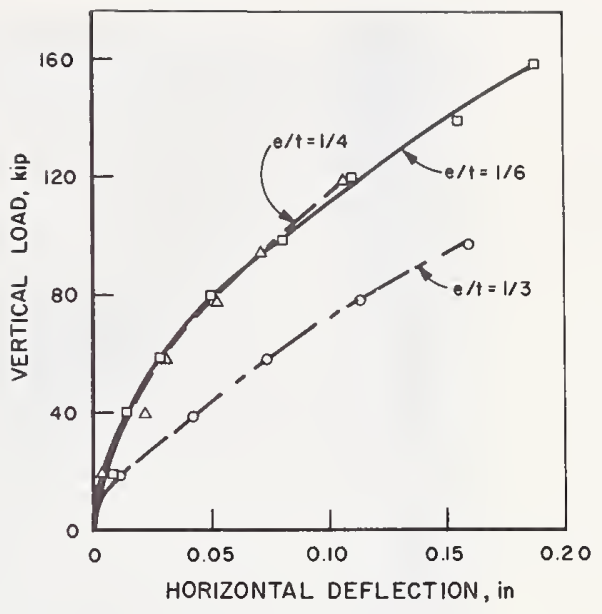

FIGURE 5.3. Load-deflection curves for 16-ft reinforced walls.

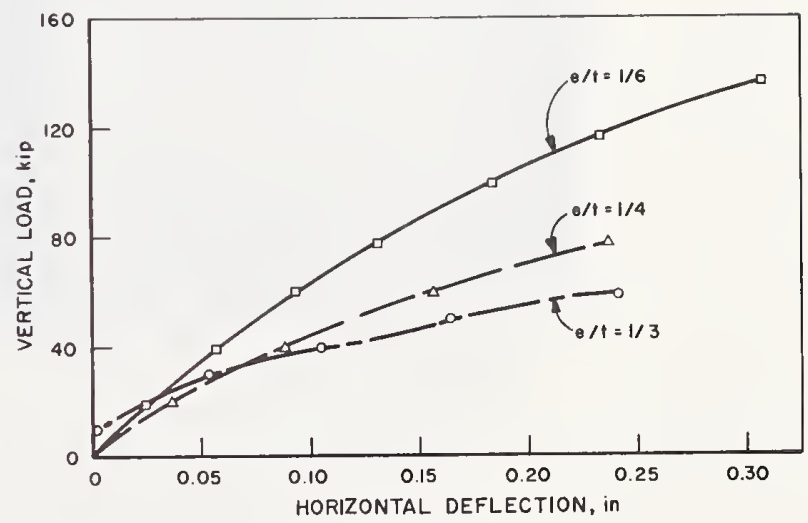

Figure 5.4. Load-deflection curves for 20 -ft reinforced walls.

tions at $\frac{3}{4}$ height of the walls which are the largest measured deflections.

Figure 5.5 shows typical wall failures. A $\log$ of all recorded individual failures is presented in table 5.2. The 10 -ft high walls with small eccentricity of load failed by vertical splitting and compression. The walls subjected to the largest eccentricity of load failed by crushing in the top 3 courses.

All of the 16-ft high walls failed along a horizontal joint, approximately $\frac{1}{4}$ the wall height from the top of the wall. These walls developed large deflections prior to failure. 


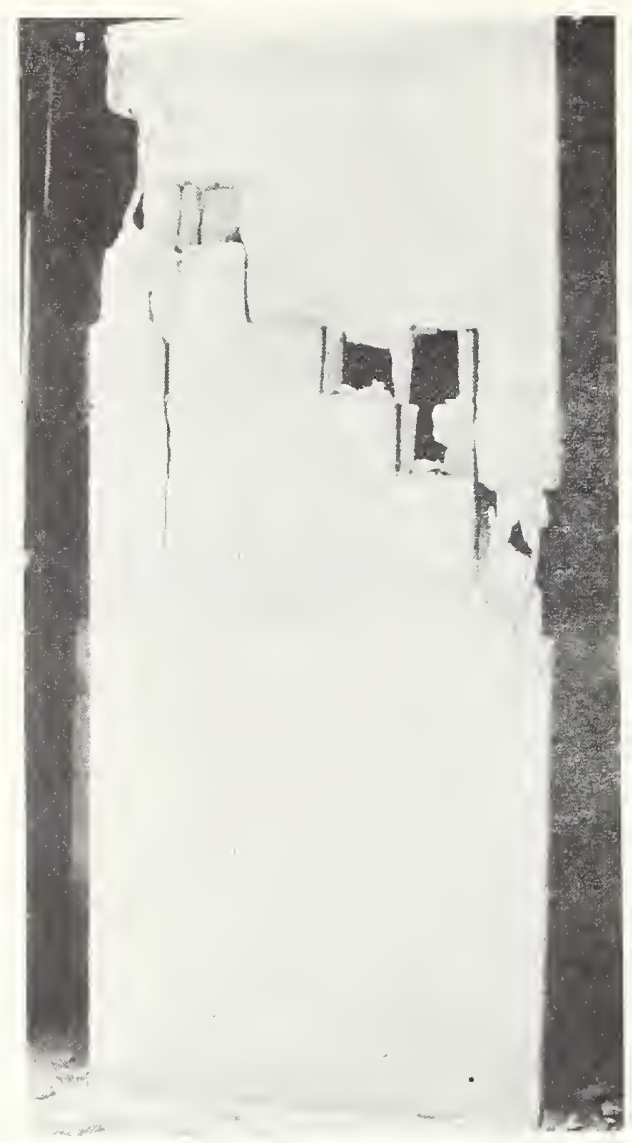

Axially Loaded 10-ft Panel

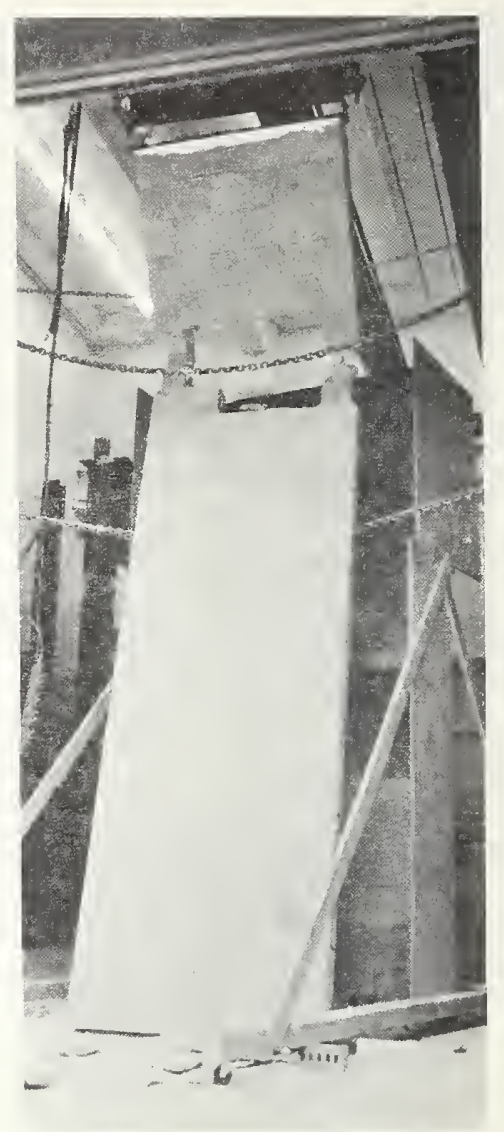

Eccentrically Looded 16-ft Panel

F1GURE 5.5. Typical failures of 6-in reinforced walls.

The 20-ft high walls also failed at horizontal joints, approximately $\frac{1}{4}$ of the wall height from the top of the wall.

Deflections of the 20 - $\mathrm{ft}$ walls were considerably larger than in the 16-ft walls. At eccentricities of $t / 4$ and $t / 3$, the walls deflected excessively and tended to slip out of the loading system. These walls recovered after load removal and exhibited only small residual deflections. Most walls crushed at a horizontal joint 6 to 7 courses below the top of the wall. 
TABLE 5.2

Failures of 6-in Reinforced Walls

\begin{tabular}{|c|c|c|c|}
\hline $\begin{array}{l}\text { Wall Spec } \\
\text { Designation }\end{array}$ & No. & $\begin{array}{l}\text { Age } \\
\text { days }\end{array}$ & Description of Failure \\
\hline $10-R-0$ & 1 & $30-32$ & $\begin{array}{l}\text { Split down one side of one face about } 1 \text { unit from end. } \\
\text { Failure occurred when top } 1 / 4 \mathrm{~h} \text { came out. }\end{array}$ \\
\hline $10-\mathrm{R}-\mathrm{T} 4$ & 7 & $14-18$ & Top failed. \\
\hline $10-\mathrm{R}-\mathrm{T} 4$ & 8 & $14-18$ & Failure in top 3 courses. \\
\hline $10-R-T 3$ & 9 & $14-15$ & Failure in top 2 courses. \\
\hline $16-R-0$ & 1 & $10-16$ & Wall broke along horiz. joint $1 / 4 \mathrm{~h}$ from top. \\
\hline $16-\mathrm{R}-0$ & 2 & $11-17$ & Wall broke along horiz. joint $1 / 4 \mathrm{~h}$ from top. \\
\hline $16-\mathrm{R}-\mathrm{T} 6$ & 3 & $7-13$ & Wall broke along horiz. joint $1 / 4 \mathrm{~h}$ from top. \\
\hline 16-R-T6 & 4 & $11-17$ & Wall broke along horiz. joint $1 / 4 \mathrm{~h}+$ from top. \\
\hline $16-\mathrm{R}-\mathrm{T} 4$ & 5 & $8-14$ & $\begin{array}{l}\text { Wall broke along horiz. joint between } 4 \text { th \& } 5 \text { th course } \\
\text { from top, compressive failure in } 5 \text { th course. }\end{array}$ \\
\hline $16-\mathrm{R}-\mathrm{T} 4$ & 6 & $9-15$ & $\begin{array}{l}\text { Wall broke along horiz. joint between } 5 \text { th \& } 6 \text { th course } \\
\text { from top. }\end{array}$ \\
\hline $16-\mathrm{R}-\mathrm{T} 3$ & 8 & $8-10$ & Failed at 6 th course from top. \\
\hline $20-R-0$ & 1 & $45-49$ & Crushing of 7 th course from top. \\
\hline $20-R-0$ & 5 & $12-18$ & $\begin{array}{l}\text { Failure occurred in the } 7 \text { th \& } 8 \text { th courses from the top. } \\
\text { A large vertical crack developed at } 214 \text { kip in the } \\
\text { instrumented part of the test. Crack extended from } 18 \text { th } \\
\text { to } 24 \text { th course. There was no top reinforcement on west } \\
\text { side of wall. }\end{array}$ \\
\hline 20-R-T6 & 3 & $19-21$ & $\begin{array}{l}\text { Crushing between } 6 \text { th \& } 7 \text { th courses from the top on the } \\
\text { compression side of wall. }\end{array}$ \\
\hline $20-\mathrm{R}-\mathrm{T} 6$ & 4 & $19-21$ & $\begin{array}{l}\text { Crushing between } 6 \text { th \& } 7 \text { th courses from the top on the } \\
\text { compression side of wall. There was a slight bend in } \\
\text { the wall about the top of the } 15 \text { th course from the } \\
\text { bottom. }\end{array}$ \\
\hline 20-R-T4 & 7 & $8-19$ & $\begin{array}{l}\text { Wall slipped out of loading system with no apparent } \\
\text { sign of failure. }\end{array}$ \\
\hline $20-R-T 4$ & 8 & $9-20$ & $\begin{array}{l}\text { Wall deflected considerably about } 2 \text { courses above bond } \\
\text { beam (mid height) then slipped away from loading system. } \\
\text { After failure had little residual deflection. }\end{array}$ \\
\hline $20-R-T 3$ & 9 & $9-13$ & $\begin{array}{l}\text { Failure occurred by excessive bending at bottom of } 7 \text { th } \\
\text { course from the top. }\end{array}$ \\
\hline 20-R-T3 & 10 & $10-14$ & $\begin{array}{l}\text { Large deflection prior to failure with greatest deflec- } \\
\text { tion } 7 \text { th course from the top. }\end{array}$ \\
\hline
\end{tabular}




\begin{tabular}{|c|c|c|c|c|c|}
\hline $\begin{array}{l}\text { Wall Spec } \\
\text { Designation }\end{array}$ & $\begin{array}{l}\text { en } \\
\text { No. }\end{array}$ & $\begin{array}{l}\text { Age } \\
\text { days }\end{array}$ & \multicolumn{2}{|c|}{$\begin{array}{c}\text { Eccentricity } \\
\text { in }\end{array}$} & $\begin{array}{l}\text { Ultimate } \\
\text { Load } \\
\text { kip }\end{array}$ \\
\hline $\begin{array}{l}10-N-0 \\
10-N-0 \\
10-N-0 \frac{a}{a} \\
10-N-0^{a}\end{array}$ & $\begin{array}{l}1 \\
2 \\
3 \\
4\end{array}$ & $\begin{array}{l}33-36 \\
35-38 \\
16-18 \\
18-20\end{array}$ & $\begin{array}{l}0 \\
0 \\
0 \\
0\end{array}$ & $\begin{array}{l}0 \\
0 \\
0 \\
0\end{array}$ & $\begin{array}{l}232.3 \\
231.7 \\
170.4 \\
159.7\end{array}$ \\
\hline $\begin{array}{l}10-N-T 6 \frac{a}{a} / b / \\
10-N-T 6=\end{array}$ & $\begin{array}{l}5 \\
6\end{array}$ & $\begin{array}{l}15 \\
18\end{array}$ & $\begin{array}{l}t / 6 \\
t / 6\end{array}$ & $\begin{array}{l}1.27 \\
1.27\end{array}$ & $\begin{array}{l}172.6 \\
166.1\end{array}$ \\
\hline $\begin{array}{l}10-\mathrm{N}-\mathrm{T} 4 \\
10-\mathrm{N}-\mathrm{T} 4^{\mathrm{b}}\end{array}$ & $\begin{array}{l}7 \\
8\end{array}$ & $\begin{array}{l}13-16 \\
15-18\end{array}$ & $\begin{array}{l}t / 4 \\
t / 4\end{array}$ & $\begin{array}{l}1.91 \\
1.91\end{array}$ & $\begin{array}{l}203.2 \\
217.2\end{array}$ \\
\hline $\begin{array}{l}10-\mathrm{N}-\mathrm{T} 3 \\
10-\mathrm{N}-\mathrm{T} 3\end{array}$ & $\begin{array}{r}9 \\
10\end{array}$ & $\begin{array}{l}13 \\
16\end{array}$ & $\begin{array}{l}t / 3 \\
t / 3\end{array}$ & $\begin{array}{l}2.54 \\
2.54\end{array}$ & $\begin{array}{l}198.4 \\
207.0\end{array}$ \\
\hline $\begin{array}{l}10-N-0 \\
10-N-0\end{array}$ & $\begin{array}{l}13 \\
14\end{array}$ & $\begin{array}{l}10-11 \\
11-12\end{array}$ & $\begin{array}{l}0 \\
0\end{array}$ & $\begin{array}{l}0 \\
0\end{array}$ & $\begin{array}{l}278.7 \\
225.2\end{array}$ \\
\hline $\begin{array}{l}10-N-T 6 \\
10-N-T 6\end{array}$ & $\begin{array}{l}11 \\
12\end{array}$ & $\begin{array}{l}12 \\
13\end{array}$ & $\begin{array}{l}t / 6 \\
t / 6\end{array}$ & $\begin{array}{l}1.27 \\
1.27\end{array}$ & $\begin{array}{l}157.4 \\
196.8\end{array}$ \\
\hline $\begin{array}{l}16-N-0 \\
16-N-0\end{array}$ & $\begin{array}{l}1 \\
2\end{array}$ & $\begin{array}{l}11-15 \\
14-18\end{array}$ & $\begin{array}{l}0 \\
0\end{array}$ & $\begin{array}{l}0 \\
0\end{array}$ & $\begin{array}{l}262.6 \\
273.5\end{array}$ \\
\hline $\begin{array}{l}16-N-T 6 \\
16-N-T 6\end{array}$ & $\begin{array}{l}3 \\
5\end{array}$ & $\begin{array}{r}14-15 \\
8-10\end{array}$ & $\begin{array}{l}t / 6 \\
t / 6\end{array}$ & $\begin{array}{l}1.27 \\
1.27\end{array}$ & $\begin{array}{l}199.7 \\
181.7\end{array}$ \\
\hline $\begin{array}{l}16-N-T 4 \\
16-N-T 4\end{array}$ & $\begin{array}{l}4 \\
6\end{array}$ & $\begin{array}{l}14-15 \\
11-13\end{array}$ & $\begin{array}{l}t / 4 \\
t / 4\end{array}$ & $\begin{array}{l}1.91 \\
1.91\end{array}$ & $\begin{array}{l}175.3 \\
172.0\end{array}$ \\
\hline $\begin{array}{l}16-N-T 3 \\
16-N-T 3\end{array}$ & $\begin{array}{l}7 \\
8\end{array}$ & $\begin{array}{l}10-11 \\
11-12\end{array}$ & $\begin{array}{l}t / 3 \\
t / 3\end{array}$ & $\begin{array}{l}2.54 \\
2.54\end{array}$ & $\begin{array}{l}166.1 \\
169.4\end{array}$ \\
\hline $\begin{array}{l}20-N-0 \\
20-N-0 \\
20-N-0 \\
20-N-0\end{array}$ & $\begin{array}{l}1 \\
2 \\
3 \\
6\end{array}$ & $\begin{array}{c}39-44 \\
39-44 \\
22 \\
12-13\end{array}$ & $\begin{array}{l}0 \\
0 \\
0 \\
0\end{array}$ & $\begin{array}{l}0 \\
0 \\
0 \\
0\end{array}$ & $\begin{array}{l}233.5 \\
249.2 \\
195.8 \\
208.1\end{array}$ \\
\hline $\begin{array}{l}20-N-T 6 \\
20-N-T 6\end{array}$ & $\begin{array}{l}4 \\
5\end{array}$ & $\begin{array}{l}22 \\
12-13\end{array}$ & $\begin{array}{l}t / 6 \\
t / 6\end{array}$ & $\begin{array}{l}1.27 \\
1.27\end{array}$ & $\begin{array}{l}188.7 \\
180.2\end{array}$ \\
\hline $\begin{array}{l}20-N-T 4 \\
20-N-T 4\end{array}$ & $\begin{array}{l}7 \\
8\end{array}$ & $\begin{array}{l}14-15 \\
14-15\end{array}$ & $\begin{array}{l}t / 4 \\
t / 4\end{array}$ & $\begin{array}{l}1.91 \\
1.91\end{array}$ & $\begin{array}{l}143.0 \\
143.0\end{array}$ \\
\hline $\begin{array}{l}20-N-T 3 \\
20-N-T 3\end{array}$ & $\begin{array}{r}9 \\
10\end{array}$ & $\begin{array}{l}8-10 \\
8-10\end{array}$ & $\begin{array}{l}t / 3 \\
t / 3\end{array}$ & $\begin{array}{l}2.54 \\
2.54\end{array}$ & $\begin{array}{l}148.1 \\
150.5\end{array}$ \\
\hline
\end{tabular}

a) Walls had some mortar joints of thickness in excess of $3 / 8$ in.

b/ Wa11 was damaged by the yoke used in transporting it.

\subsection{8-in Unreinforced Walls}

The wall test results are summarized in table 5.3 and plotted in figure 5.6. Figures 5.7 through 5.9 show load-deflection curves for the deflections at $\frac{3}{4}$ height of the 8-in walls.

Wall failures are shown in figure 5.10. A log of all recorded individual failures is shown in table 5.4.

The 10-ft high walls failed in a manner resembling the failure of three-block high prisms. Axially loaded walls developed vertical cracks with final failure occurring by crushing between the second and fourth course from the top or bottom end of the wall at both wall faces. Eccentrically loaded walls failed between the top and the fourth course from the top by compressive failure on one wall face at a mortar joint, except for one wall loaded at an eccentricity of $t / 6$ which failed near its base.

The 16-ft high walls generally failed along a horizontal joint at approximately $\frac{3}{4}$ of their height. One axially loaded wall and one wall loaded at an eccentricity of $t / 6$ failed by compression near the second course from the bottom of the wall.

Most 20 - $\mathrm{ft}$ high walls also failed along a horizontal joint at approximately $\frac{3}{4}$ of their height. One axially loaded wall and one with a load eccentricity of $t / 6$ failed by crushing of the mortar joint three courses from the bottom. 

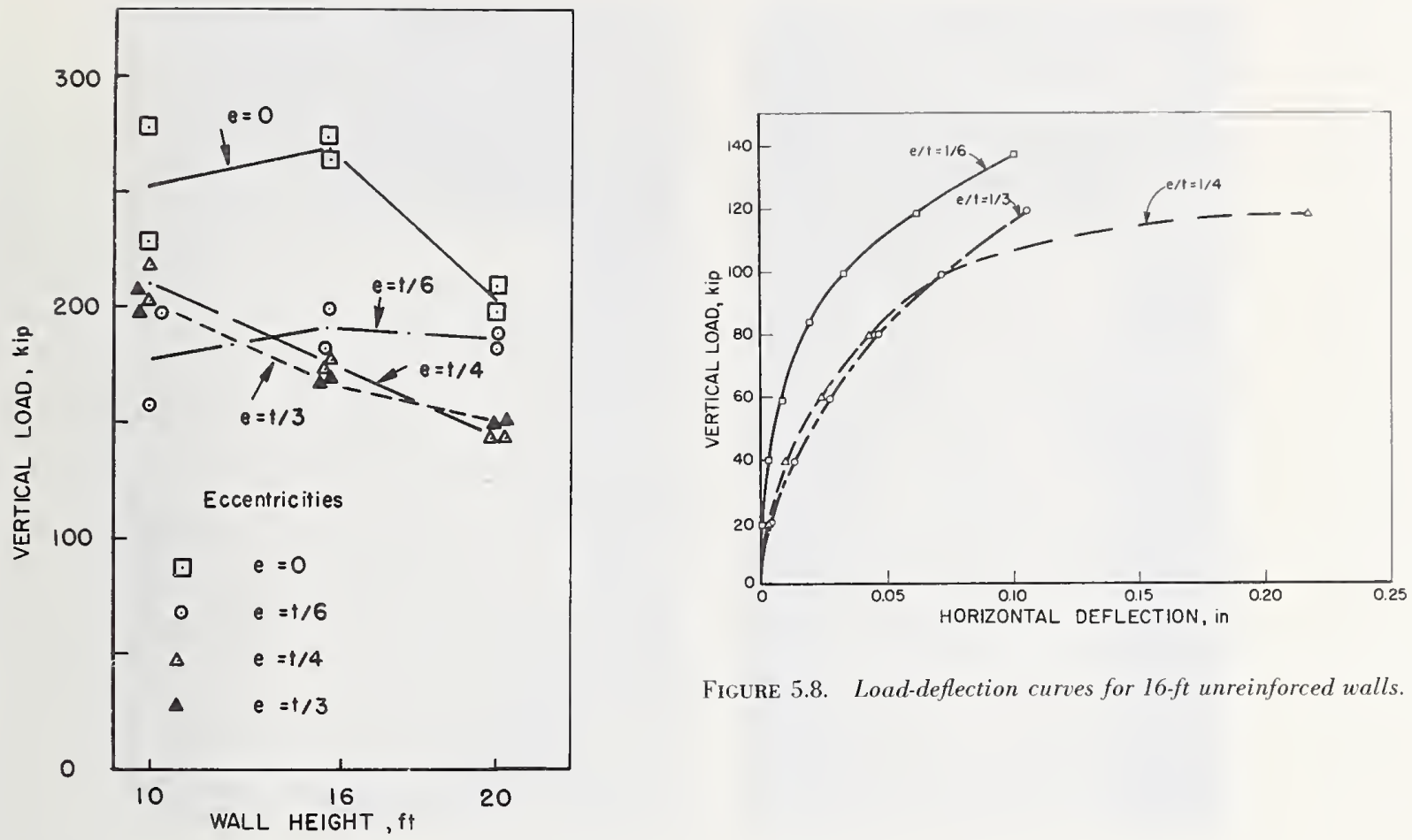

FigURE 5.8. Load-deflection curves for 16-ft unreinforced walls.

Figune 5.6. Failure loads for 8-in unreinforced walls.
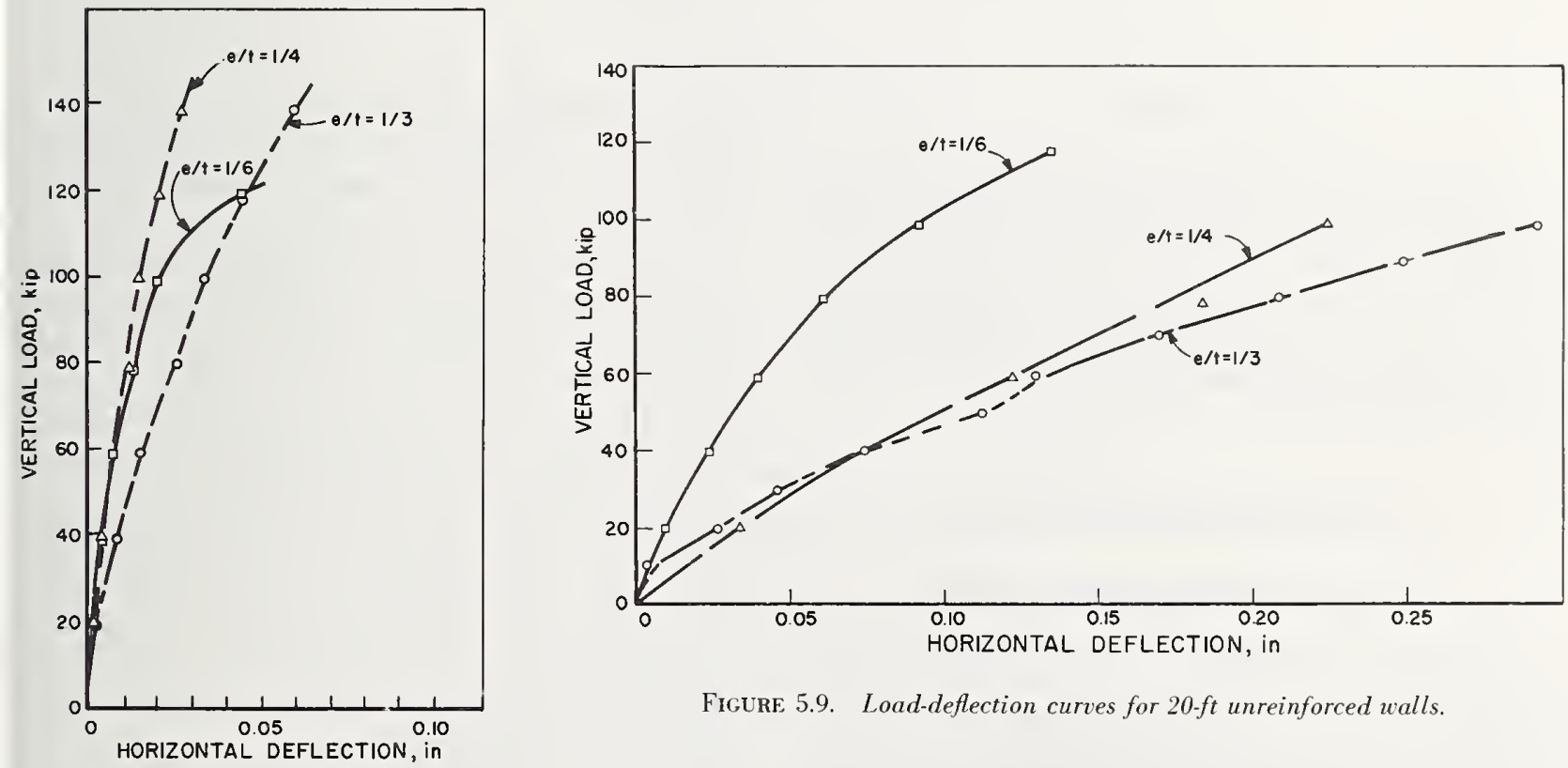

FIGURE 5.9. Load-deflection curves for 20-ft unreinforced walls.

Figure 5.7. Load-deflection curves for 10-ft unreinforced walls. 

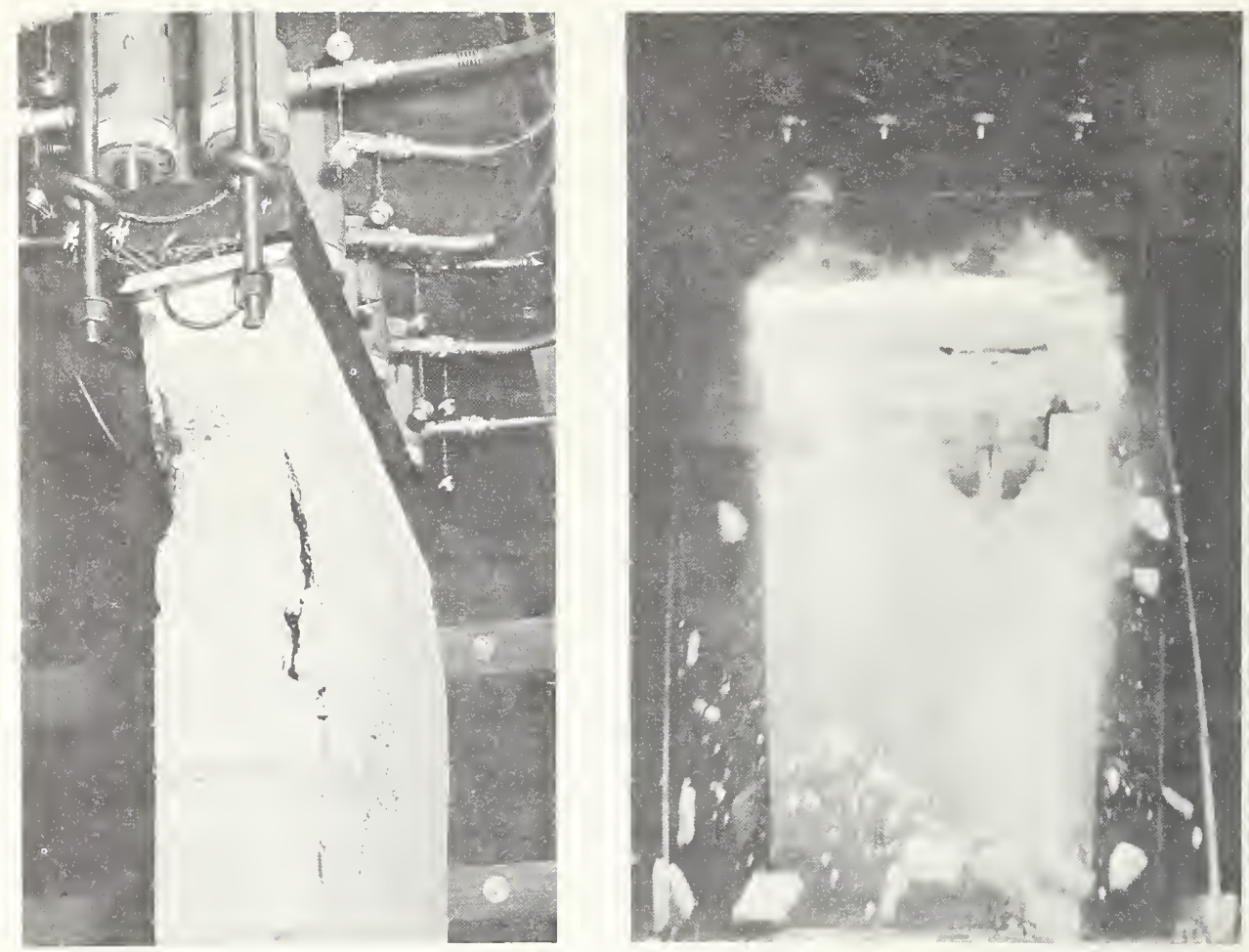

FIgURE 5.10. Typical failures of 8-in unreinforced walls.

\subsection{Prisms}

Test results on eccentrically loaded 2-block high and 3-block high prisms made of 6-in and 8-in block are given in tables 5.5 and 5.6, respectively. These tables note the age, as well as the date of fabrication of prisms. This is noted since the strength of prisms fabricated on certain dates sometimes deviated markedly from the generally observed trend.

\section{Interpretation of Results}

\subsection{Stress-Strain Relationships}

Stress-strain relationships, measured on unreinforced as well as reinforced walls, are shown in figure 6.1. Curve A shows a stress-strain curve computed from the longitudinal deformation of an axially loaded 16-ft unreinforced wall (specimen 2). This is the only case where deflections were measured to the point of ultimate load. In all other cases instrumentation was removed prior to failure. Curves B and $\mathrm{C}$ are stress-strain curves for axially loaded $10-\mathrm{ft}$ unreinforced walls, computed from the average of measurements of 4 linear variable differential transformers having a gage length of $24 \mathrm{in}$, which were specially installed for that purpose. (Curve B is for specimen 14 and curve $C$ for specimen 4.) Curve $C$ was obtained from one of the specimens with excessive joint thickness and may therefore represent a wall of lower than normal strength. The ultimate compressive strength of the specimens from which curves $B$ and $C$ were derived is also shown in the figure. Stress was computed on the basis of the average net area, determined in accordance with ASTM Standard C140-65T.

There is good agreement between the three curves. In general, the measured stress-strain 
TABLE 5.4 Failures of 8-in Unreinforced Walls

\begin{tabular}{|c|c|c|c|}
\hline \multicolumn{2}{|c|}{ Wa11 Specimen } & \multirow{2}{*}{$\begin{array}{l}\text { Age } \\
\text { days }\end{array}$} & \multirow{2}{*}{ Description of Failure } \\
\hline Designation & No. & & \\
\hline $10-\mathrm{N}-0$ & 1 & $33-36$ & $\begin{array}{l}\text { Wall split through center vertically to bottom } \\
1 / 4 \text { h where it broke down and out to bottom } \\
\text { corners. Typical compression failure of block. }\end{array}$ \\
\hline $10-N-0$ & 2 & $35-38$ & Compression failure in 2nd course from bottom. \\
\hline $10-\mathrm{N}-0$ & 3 & $16-18$ & $\begin{array}{l}\text { Vertical splitting and cracking in the shape of } \\
\text { an inverted } V \text { at top } 1 / 4 \text { h point of wall. }\end{array}$ \\
\hline $10-\mathrm{N}-\mathrm{T} 4$ & 7 & $13-16$ & $\begin{array}{l}\text { Bending with subsequent compression failure in } \\
\text { mortar joint at yoke location (top of } 9 \text { th course). }\end{array}$ \\
\hline $10-\mathrm{N}-\mathrm{T} 3$ & 9 & 13 & $\begin{array}{l}\text { Bending in the wal1, compressive failure in the } \\
\text { mortar joint on inside of bend and sudden rupture. }\end{array}$ \\
\hline $10-\mathrm{N}-\mathrm{T} 3$ & 10 & 16 & $\begin{array}{l}\text { Bending and subsequent failure at the mortar } \\
\text { joint between 3rd and } 4 \text { th courses from the top. }\end{array}$ \\
\hline $10-\mathrm{N}-\mathrm{T} 6$ & 11 & 12 & Splitting of 1st and 2nd courses from the bottom. \\
\hline $16-N-0$ & 1 & $11-15$ & $\begin{array}{l}\text { Wa } 11 \text { broke about } 1 / 4 \text { h from top along a horizontal } \\
\text { joint and blew out of frame. }\end{array}$ \\
\hline $16-N-0$ & 2 & $14-18$ & $\begin{array}{l}\text { Compression failure in 2nd course from bottom, } \\
\text { wall broke up and fell straight down. }\end{array}$ \\
\hline $16-\mathrm{N}-\mathrm{T} 6$ & 3 & $14-15$ & $\begin{array}{l}\text { Compression failure in } 1 \text { st and } 2 \text { nd courses from } \\
\text { bottom, wa } 11 \text { broke along horizontal joint } 1 / 4 \mathrm{~h} \\
\text { from bottom. }\end{array}$ \\
\hline $16-\mathrm{N}-\mathrm{T} 6$ & 5 & $8-10$ & $\begin{array}{l}\text { Wa } 11 \text { broke along horizontal joint between } 1 / 3 \mathrm{~h} \\
\text { and } 1 / 4 \mathrm{~h} \text { from the top. }\end{array}$ \\
\hline $16-\mathrm{N}-\mathrm{T} 4$ & 4 & $14-15$ & $\begin{array}{l}\text { Wall broke along horizontal joint } 1 / 4 \mathrm{~h} \text { from the } \\
\text { top. }\end{array}$ \\
\hline $16-\mathrm{N}-\mathrm{T} 4$ & 6 & $11-13$ & $\begin{array}{l}\text { Failure originated at 2nd course from top and wall } \\
\text { fell sideways. }\end{array}$ \\
\hline $16-\mathrm{N}-\mathrm{T} 3$ & 8 & $11-12$ & Failed at 6 th joint from top. \\
\hline $20-\mathrm{N}-0$ & 1 & $39-44$ & $\begin{array}{l}\text { Failure } 5 \text { th course from the top }-2 / 3 \text { way through } \\
\text { test vertical cracking in } 2 \text { nd and } 3 \text { rd courses } \\
\text { from bottom. }\end{array}$ \\
\hline $20-N-0$ & 3 & 22 & Failed near the top. \\
\hline $20-\mathrm{N}-0$ & 6 & $12-13$ & Crushing about 3 rd course from the bottom. \\
\hline $20-\mathrm{N}-\mathrm{T} 6$ & 4 & 22 & $\begin{array}{l}\text { Failure occurred } 5 \text { th course from top along } \\
\text { horizontal joint. }\end{array}$ \\
\hline $20-\mathrm{N}-\mathrm{T} 6$ & 5 & $12-13$ & Failure in mortar joint 3 rd course from the bottom. \\
\hline $20-\mathrm{N}-\mathrm{T} 4$ & 7 & $14-15$ & $\begin{array}{l}\text { Failure occurred } 1 / 4 \mathrm{~h} \text { from top, very little deflec- } \\
\text { tion was visible prior to failure. }\end{array}$ \\
\hline $20-\mathrm{N}-\mathrm{T} 4$ & 8 & $14-15$ & Failure occurred about $1 / 5 \mathrm{~h}$ from the top. \\
\hline $20-N-T 3$ & 9 & $8-10$ & Failure occurred near 7 th course from the top. \\
\hline $20-\mathrm{N}-\mathrm{T} 3$ & 10 & $8-10$ & $\begin{array}{l}\text { Spalling at 2nd course from top. Failure at } 6 \text { th } \\
\text { course from top. }\end{array}$ \\
\hline
\end{tabular}




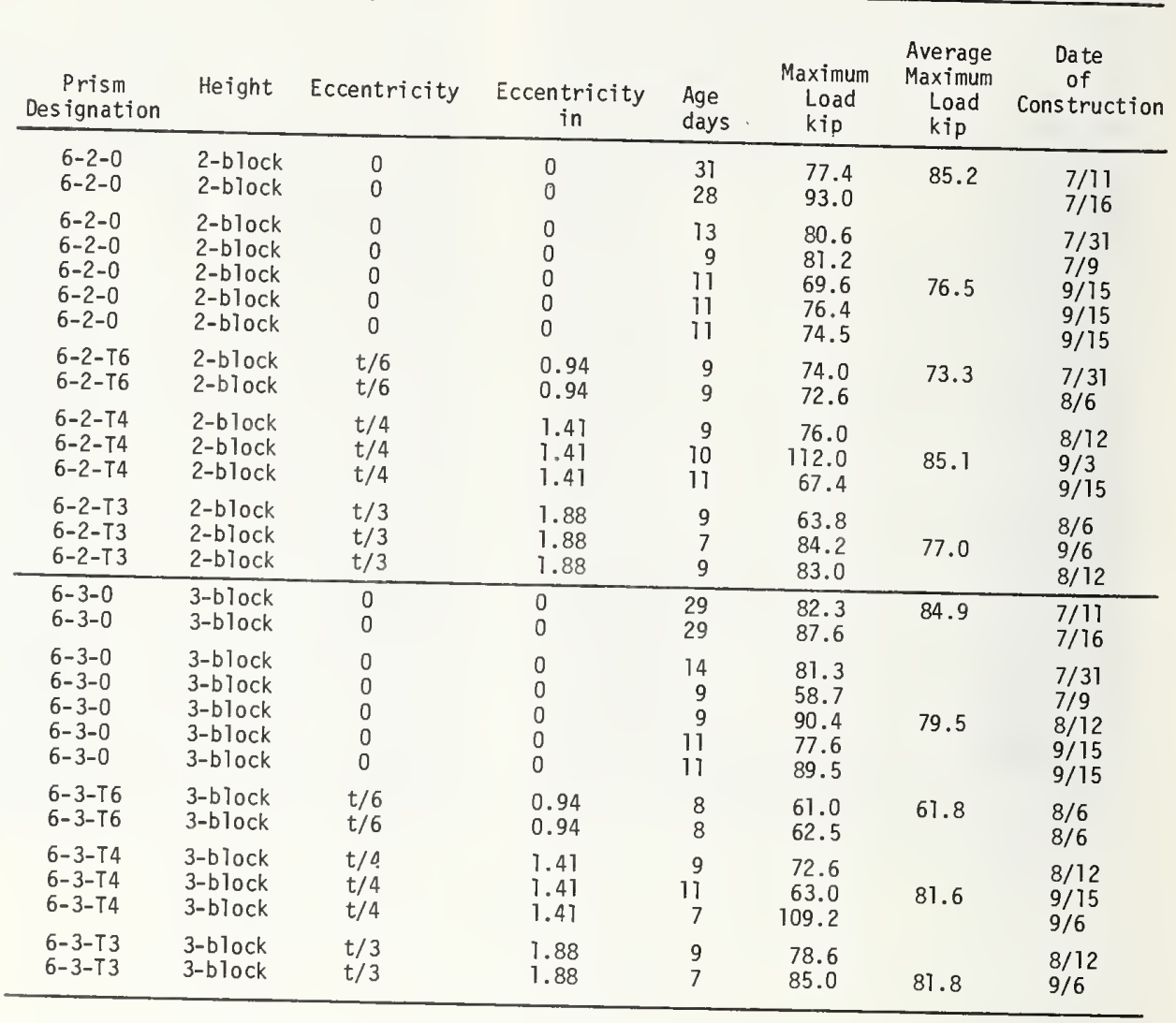

curves can be approximated by a straight line. Curve $A$, which is the only curve that covers stress-strain relations to the point of failure, was derived from a specimen of higher-than-average strength. This curve therefore covers a range of stresses not normally developed by a typical specimen.

The following values of moduli of elasticity were experimentally derived for the unreinforced walls:

Initial modulus of elasticity, $E_{i}=1.4 \times 10^{6} \mathrm{psi}$.

Approximate final tangent modulus of elasticity at the stress level of most wall failures, $E_{t}=$ $0.4 \times 10^{6} \mathrm{psi}$.

Curve D in figure 6.1 shows stress-strain relationships for an axially loaded reinforced 10 -ft wall. In this case, stresses were determined on the basis of the transformed section shown in figure 6.2. This transformed section was developed using a "net" cross-sectional area for the block which is based on minimum face-shell and web thicknesses, the area of the grout and a transformed steel area based on an " $n$ " of 29 assuming that the average modulus of elasticity of masonry is approximately $1 \times 10^{6} \mathrm{psi}$ and that of steel is $29 \times 10^{6}$ psi. It can be seen from a comparison of curve $D$ with curves $A, B$ and $C$ that the area transformation which conservatively assumed equal stiffness for grout and masonry and also was based on minimum, rather than average, net area of masonry probably resulted in overestimating the stresses in the masonry.

The value of the initial modulus of elasticity derived from curve $\mathrm{D}$ is $2.8 \times 10^{6} \mathrm{psi}$. A tangent modulus at failure could not be obtained since instrumentation was removed before the masonry developed its ultimate strength. Note that the stressstrain curve is essentially linear up to a stress of about 80 percent of the failure stress. A linear stressstrain relationship probably approximates the stress distribution up to failure reasonably well. 
TABLE 5.6 Summary of 8-in Prism Test Results

\begin{tabular}{|c|c|c|c|c|c|c|c|}
\hline $\begin{array}{c}\text { Prism } \\
\text { Designation }\end{array}$ & He ight & Eccentricity & $\begin{array}{l}\text { Eccentricity } \\
\text { in }\end{array}$ & $\begin{array}{l}\text { Age } \\
\text { days }\end{array}$ & $\begin{array}{l}\text { Maximum } \\
\text { Load } \\
\text { kip }\end{array}$ & $\begin{array}{l}\text { Average } \\
\text { Maximum } \\
\text { Load } \\
\text { kip }\end{array}$ & $\begin{array}{c}\text { Date } \\
\text { of } \\
\text { Construction }\end{array}$ \\
\hline $\begin{array}{l}8-2-0 \\
8-2-0\end{array}$ & $\begin{array}{l}\text { 2-block } \\
\text { 2-block }\end{array}$ & $\begin{array}{l}0 \\
0\end{array}$ & $\begin{array}{l}0 \\
0\end{array}$ & $\begin{array}{l}28 \\
28\end{array}$ & $\begin{array}{l}109.5 \\
107.5\end{array}$ & 108.5 & $\begin{array}{l}7 / 17 \\
7 / 18\end{array}$ \\
\hline $\begin{array}{l}8-2-0 \\
8-2-0 \\
8-2-0 \\
8-2-0 \\
8-2=0\end{array}$ & $\begin{array}{l}\text { 2-block } \\
\text { 2-block } \\
\text { 2-block } \\
\text { 2-block } \\
\text { 2-block }\end{array}$ & $\begin{array}{l}0 \\
0 \\
0 \\
0 \\
0\end{array}$ & $\begin{array}{l}0 \\
0 \\
0 \\
0 \\
0\end{array}$ & $\begin{array}{l}14 \\
13 \\
12 \\
12 \\
11\end{array}$ & $\begin{array}{r}77.0 \\
87.6 \\
75.2 \\
71.0 \\
112.0\end{array}$ & 84.6 & $\begin{array}{l}7 / 1 \\
7 / 2 \\
7 / 31 \\
7 / 31 \\
9 / 15\end{array}$ \\
\hline $\begin{array}{l}8-2-T 6 \\
8-2-T 6\end{array}$ & $\begin{array}{l}\text { 2-blcck } \\
\text { 2-block }\end{array}$ & $\begin{array}{l}t / 6 \\
t / 6\end{array}$ & $\begin{array}{l}1.27 \\
1.27\end{array}$ & $\begin{array}{l}15 \\
12\end{array}$ & $\begin{array}{l}82.6 \\
72.0\end{array}$ & 77.3 & $\begin{array}{l}7 / 2 \\
7 / 17\end{array}$ \\
\hline $\begin{array}{l}8-2-T 4 \\
8-2-T 4 \\
8-2-T 4\end{array}$ & $\begin{array}{l}\text { 2-block } \\
\text { 2-block } \\
\text { 2-block }\end{array}$ & $\begin{array}{l}t / 4 \\
t / 4 \\
t / 4\end{array}$ & $\begin{array}{l}1.91 \\
1.91 \\
1.91\end{array}$ & $\begin{array}{r}13 \\
13 \\
9\end{array}$ & $\begin{array}{l}69.3 \\
71.0 \\
84.6\end{array}$ & 75.0 & $\begin{array}{l}7 / 18 \\
7 / 18 \\
8 / 12\end{array}$ \\
\hline $\begin{array}{l}8-2-T 3 \\
8-2-T 3 \\
8-2-T 3 \\
8-2-T 3\end{array}$ & $\begin{array}{l}\text { 2-block } \\
\text { 2-block } \\
\text { 2-block } \\
\text { 2-block }\end{array}$ & $\begin{array}{l}t / 3 \\
t / 3 \\
t / 3 \\
t / 3\end{array}$ & $\begin{array}{l}2.54 \\
2.54 \\
2.54 \\
2.54\end{array}$ & $\begin{array}{r}11 \\
8 \\
19 \\
9\end{array}$ & $\begin{array}{l}72.0 \\
60.6 \\
58.5 \\
94.6\end{array}$ & 71.4 & $\begin{array}{l}9 / 15 \\
7 / 29 \\
8 / 6 \\
8 / 12\end{array}$ \\
\hline $\begin{array}{l}8-3-0 \\
8-3-0 \\
3-3-0\end{array}$ & $\begin{array}{l}\text { 3-block } \\
\text { 3-block } \\
\text { 3-block }\end{array}$ & $\begin{array}{l}0 \\
0 \\
0\end{array}$ & $\begin{array}{l}0 \\
0 \\
0\end{array}$ & $\begin{array}{l}28 \\
31 \\
29\end{array}$ & $\begin{array}{r}78.3 \\
101.0 \\
87.6\end{array}$ & 89.0 & $\begin{array}{l}7 / 18 \\
7 / 17 \\
7 / 17\end{array}$ \\
\hline $\begin{array}{l}8-3-0 \\
8-3-0 \\
8-3-0 \\
8-3-0\end{array}$ & $\begin{array}{l}\text { 3-block } \\
\text { 3-block } \\
\text { 3-block } \\
\text { 3-block }\end{array}$ & $\begin{array}{l}0 \\
0 \\
0 \\
0\end{array}$ & $\begin{array}{l}0 \\
0 \\
0 \\
0\end{array}$ & $\begin{array}{l}14 \\
13 \\
11 \\
11\end{array}$ & $\begin{array}{r}87.8 \\
89.2 \\
117.0 \\
91.5\end{array}$ & 96.4 & $\begin{array}{l}7 / 1 \\
7 / 2 \\
9 / 15 \\
9 / 15\end{array}$ \\
\hline $\begin{array}{l}8-3-T 6 \\
8-3-T 6 \\
8-3-T 6\end{array}$ & $\begin{array}{l}\text { 3-block } \\
\text { 3-block } \\
\text { 3-block }\end{array}$ & $\begin{array}{l}t / 6 \\
t / 6 \\
t / 6\end{array}$ & $\begin{array}{l}1.27 \\
1.27 \\
1.27\end{array}$ & $\begin{array}{l}14 \\
11 \\
15\end{array}$ & $\begin{array}{l}64.7 \\
62.6 \\
67.8\end{array}$ & 65.0 & $\begin{array}{l}7 / 17 \\
7 / 18\end{array}$ \\
\hline $\begin{array}{l}8-3-T 4 \\
8-3-T 4 \\
8-3-T 4\end{array}$ & $\begin{array}{l}\text { 3-block } \\
\text { 3-block } \\
\text { 3-block }\end{array}$ & $\begin{array}{l}t / 4 \\
t / 4 \\
t / 4\end{array}$ & $\begin{array}{l}1.91 \\
1.91 \\
1.91\end{array}$ & $\begin{array}{r}13 \\
13 \\
9\end{array}$ & $\begin{array}{l}56.9 \\
58.2 \\
65.2\end{array}$ & 60.1 & $\begin{array}{l}7 / 18 \\
7 / 18 \\
8 / 12\end{array}$ \\
\hline $\begin{array}{l}8-3-T 3 \\
8-3-T 3 \\
8-3-T 3\end{array}$ & $\begin{array}{l}\text { 3-block } \\
\text { 3-block } \\
\text { 3-block }\end{array}$ & $\begin{array}{l}t / 3 \\
t / 3 \\
t / 3\end{array}$ & $\begin{array}{l}2.54 \\
2.54 \\
2.54\end{array}$ & $\begin{array}{r}15 \\
14 \\
9\end{array}$ & $\begin{array}{l}53.4 \\
48.3 \\
71.6\end{array}$ & 57.7 & $\begin{array}{l}7 / 29 \\
7 / 30 \\
8 / 12\end{array}$ \\
\hline
\end{tabular}

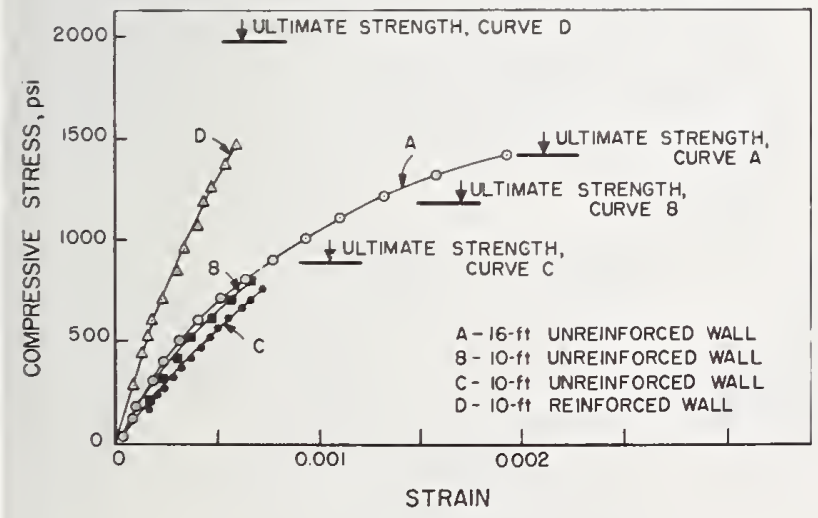

Figure 6.1. Stress-strain curves.
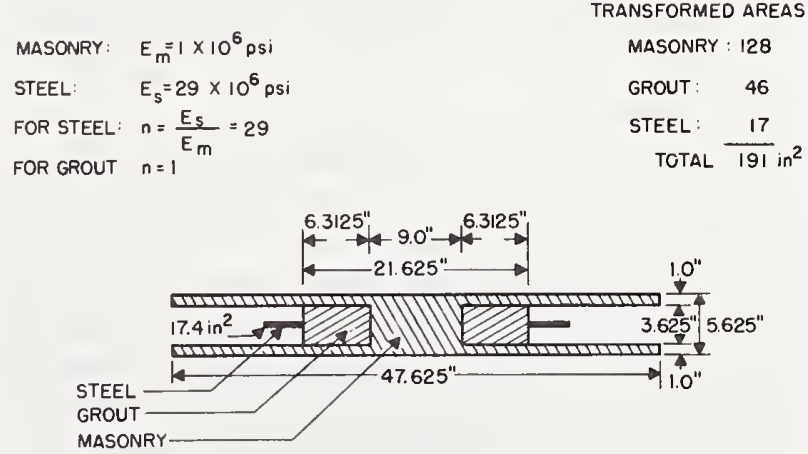

FiguRE 6.2. Assumed transformed area for reinforced masonry wall. 


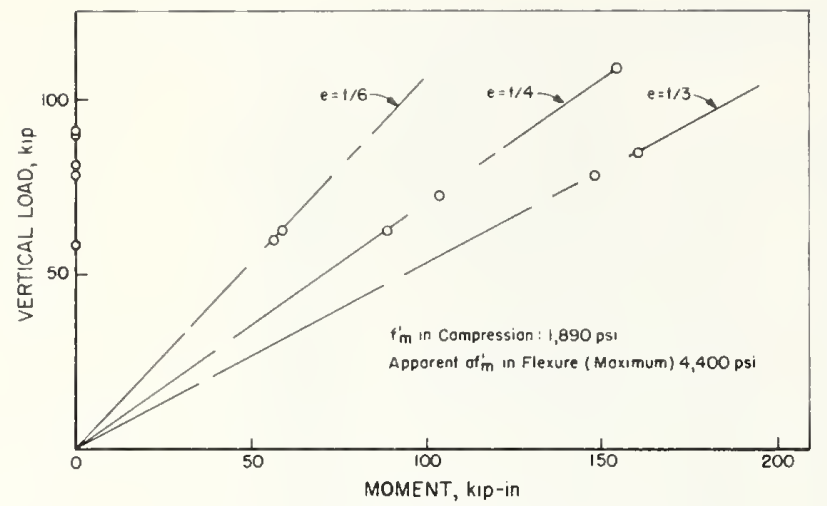

FIGURE 6.3. 6-in hollow block prisms under eccentric loading.

\subsection{Cross-Sectional Capacity}

In order to study the capacity of slender walls, it is first necessary to consider the strength of short wall sections. Figure 6.3 shows a plot of the failure loads of eccentrically loaded three-block high 6-in prisms. Loads were applied axially and at eccentricities of $t / 6, t / 4$ and $t / 3$. Note that even though there is considerable difference between individual test points at the same eccentricity, no trend can be observed for the failure load to decrease with increasing eccentricity. Similar behavior has been observed elsewhere for solid sections of concrete as well as clay-masonry [8]. It is apparent that flexural compressive strength of masonry increases significantly with increasing strain gradients.

The 6-in block of which prisms were tested were used in the construction of the reinforced masonry walls. However, these walls also contained grout and steel, and the section capacity of a reinforced wall will depend on the strength and relative stiffness of all the component materials. The correlation between prism strength and wall strength is discussed below.

The average axial compressive prism strength computed from the 6-in prism tests, based on minimum net area, is 1890 psi. This stress, multiplied by the transformed area shown in figure 6.2 (191 $\mathrm{in}^{2}$ ), results in a computed axial failure load of $361 \mathrm{kip}$. This should be compared with the average 336 -kip failure load for the 10 -ft axially loaded reinforced walls. Thus the 10 -ft walls developed approximately the predicted ultimate axial strength. This is a good correlation, considering the difference between individual test points.

It is somewhat more difficult to compare flexural compressive strength, since at each eccentricity the 6-in prisms developed different flexural compressive strength, with an apparent increase in strength with increasing strain gradients. Average flexural compressive strengths developed at an eccentricity of $t / 3$ by the 6 -in prisms and by the $10-\mathrm{ft}$ reinforced walls respectively, are compared below. The transformed section in figure 6.2 was used to compute stresses in the reinforced walls. The following stresses were computed:

Average flexural strength of 6 -in prisms, at $t / 3$ eccentricity: 4,400 psi; Average flexural strength of $10-\mathrm{ft}$ walls, at $t / 3$ eccentricity: 2,900 psi.

Stresses were computed for a linear stress distribution. While the 6 -in prisms developed flexural compressive strength which exceeded the strength under axial loading by as much as 130 percent, the strength increase in the case of the wall was only 50 percent. Thus, there is good correlation between wall strength and prism strength under axial loading, while under eccentric loading the prisms developed higher flexural compressive strength than the walls. The question arises whether the strength of the $10-\mathrm{ft}$ wall was reduced by slenderness effects. The failure mode of these walls indicates that they failed near the top, where the eccentric load was applied. It will be explained later that this type of failure is an indication that slenderness had no significant effect on wall strength. The discrepancy between flexural strength of prisms and walls is probably caused by composite action of the wall rather than by slenderness effects.

Figure 6.4 shows the failure loads of the 10 -ft high reinforced walls, plotted against applied moments

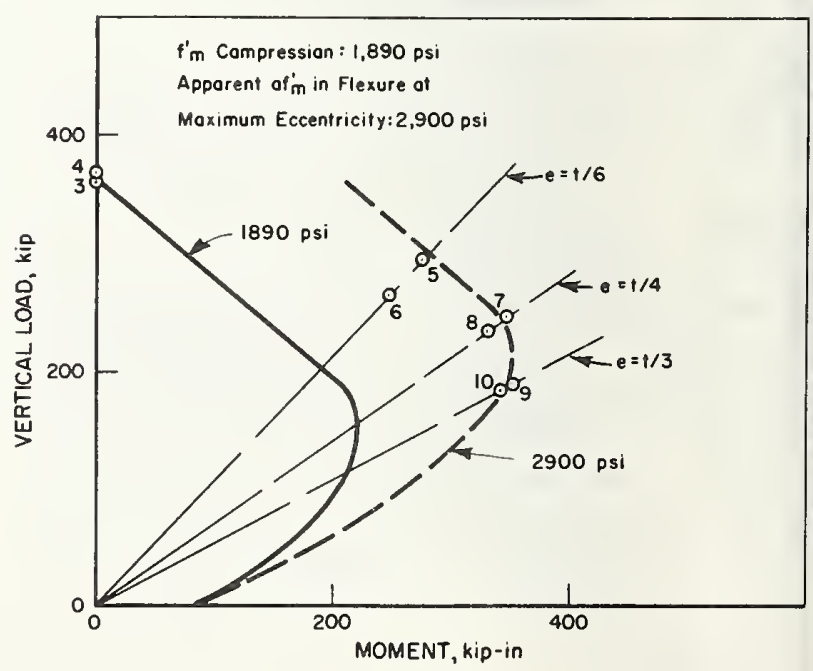

Figure 6.4. Short-wall interaction-curve and test results for 10-ft high reinforced masonry walls. 
(load $\times$ eccentricity). Test points for individual specimens are numbered in accordance with table 5.1. If it is assumed that the strength of the $10-\mathrm{ft}$ walls was not appreciably affected by slenderness, this plot also represents the cross-sectional capacity of these walls. The solid curve shown in the figure is a theoretical interaction curve for the section capacity of this wall. Moments were computed on the assumption that at failure plane sections remain plane and that the stress distribution was approximately linear. The transformed section in figure 6.2 was used in the computations. The yield strength of the steel, $f^{\prime}{ }_{s}$, was taken as $60,000 \mathrm{psi}$, and $f^{\prime}{ }_{m}$, the compressive strength of masonry, was computed from the average prism strength under axial load as 1890 psi. Additional information pertaining to the development of theoretical interaction curves is contained in reference [8].

It can be seen by comparing the actual test results with the intersection points of the solid interaction curve with the dashed sloping lines representing the various load eccentricities of the tests, that moment capacities are very conservatively predicted. Another interaction curve has been computed, using the average flexural compressive strength of 2,900 psi, developed by the walls at the maximum test eccentricity of $t / 3$. This curve is shown by the dashed line in figure 6.4. Note that this curve agrees with actual test results only at the $t / 3$ eccentricity. At smaller eccentricities the curve overestimates wall strength, and it is apparent by the way the curve diverges from the test results that flexural strength increased with increasing eccentricity. If this observation is extrapolated to eccentricities greater than $t / 3$, it may be deduced that the curve is conservative for eccentricities greater than $t / 3$, but overestimates moment capacities for eccentricities smaller than $t / 3$. If we define flexural strength as $a f^{\prime}{ }_{m}$, where $a$ is

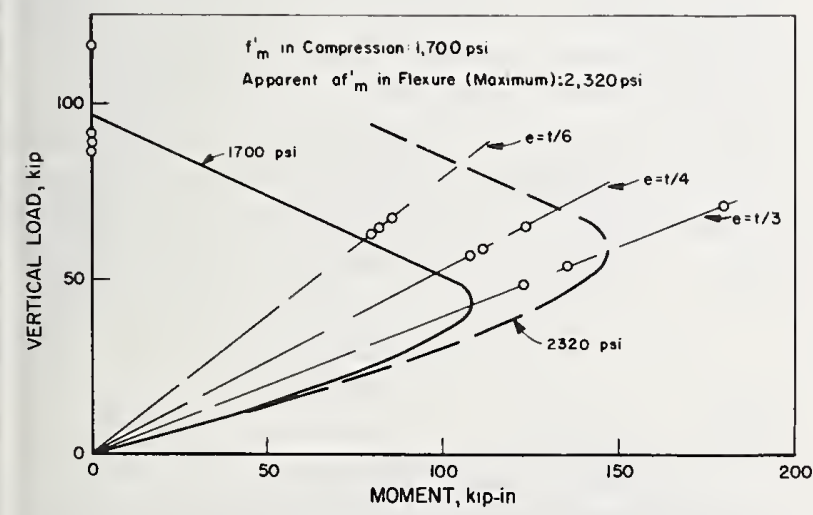

FigURE 6.5. 8-in hollow block prisms under eccentric loading. a function of load eccentricity (or strain gradients). then for the test results of the reinforced walls at $t / 3$ eccentricity $a \simeq 1.5$.

Figure 6.5 shows a plot of the failure loads of three-block high 8-in prisms subjected to axial and eccentric vertical loads. Again an interaction curve was computed on the basis of average axial compressive strength, ${f^{\prime}}_{m}=1700 \mathrm{psi}$. This curve is represented by the solid curve in figure 6.5 . It can be seen that moment capacities are very conservatively predicted by this curve. Another interaction curve has been developed on the basis of the average flexural compressive strength at the $t / 3$ eccentricity and is shown in the figure by the dashed curve. As in the case of the reinforced walls this curve diverges from the trend of the test results at smaller eccentricities. indicating that " $a$ " is a function of strain gradients. Again it may be deduced that the dashed curve is probably conservative for load eccentricities greater than $t / 3$, while overestimating capacities for smaller load eccentricity. In this case $a f^{\prime} m$ at the $t / 3$ eccentricity is 2,320 psi and $a=1.37$.

A comparison of prism strength with $10-\mathrm{ft}$ wall panel strength is shown in figure 6.6. The interaction curves for $a=1$ and $a=1.37$, developed from the prism data, are also plotted in the figure. Note that at the larger eccentricities average wall strength exceeded prism strength, while under axial loading and at the $t / 6$ eccentricity, wall strength tended to be somewhat lower than prism strength. A comparison of all the eccentric wall tests seems to show no noticeable effect of the magnitude of load eccentricity on failure load. However, there is considerable scatter in experimental results at axial load and at the $t / 6$ eccentricity. In general there appears to be no trend for the section capacity to decrease at this

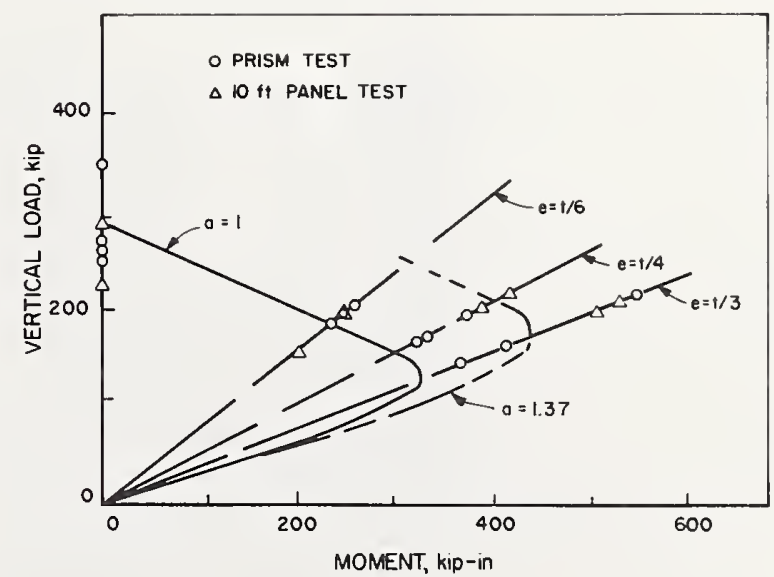

FIGURE 6.6. Comparison of prism strength and 10-ft panel strength for unreinforced walls. 
wall height. The interaction curve developed on the basis of axial strength is, in general, conservative for eccentric loads, although one wall test each at axial load and at $t / 6$ eccentricity falls below the predicted strength. This scatter appears to be caused primarily by strength variations between individual test specimens.

\subsection{Slenderness Effects}

\subsubsection{General}

Slenderness effects are illustrated in figure 6.7 which shows the free body diagram of the upper part of a wall, subject to a vertical load $P$ applied at its top at an eccentricity $e$. The free body is in equilibrium when force $P$ is resisted at the bottom of the free body by the resultant colinear force $P^{\prime}$. If the wall deflected at the bottom of the free body by an amount $\delta$ relative to the line of action of the vertical force, the resisting moment acting at the base of the free body will be $P(e+\delta)$, and thus, the external moment acting at the top of the wall will be magnified by the amount $P \cdot \delta$.

It has been shown [9] that for the case of reinforced concrete columns the maximum moment can be approximately computed by the following equation:

$$
M=P e \frac{C_{m}}{1-\frac{P}{P_{c r}}} \geqslant P e
$$

where $C_{m}$ is a correction factor, relating different moment distributions to the basic case of a pin ended column acted upon by a vertical load at equal eccentricities at the top and the bottom, $\left(C_{m}=1\right.$ for

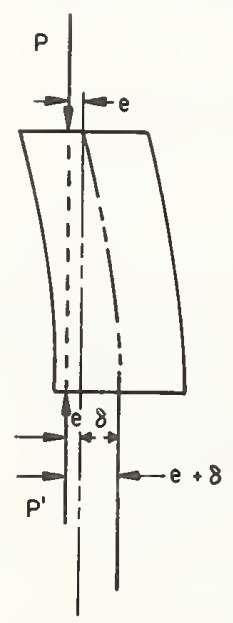

Figure 6.7. Slenderness effects. this case) and

$$
P_{c r}=\frac{\pi^{2} E I}{(k h)^{2}}
$$

is the axial load that will cause stability-induced compression failure. " $k$ " in the term $k h$ is a "length coefficient," by which height is adjusted to equivalent height, accounting for end support conditions.

In the case of masonry walls a similar mechanism will cause a decrease in wall strength with increasing wall slenderness. Inspection of the wall failure descriptions in tables 5.2 and 5.4 reveals a general trend for the more slender walls to fail in flexure along a horizontal joint in the vicinity of the point of maximum deflection, while shorter walls tended to fail near the top where the eccentricity of the applied load relative to the undeflected wall is greatest. However, the magnitude of this moment magnifier effect in the case of masonry walls depends on several parameters:

(1) End Fixity: The flat ended condition of these tests appears to resemble fixed ended conditions at the base of the wall. However, previous experience with similar conditions in brick walls [10] indicates, that while the effect of eccentrically applied loads can be approximately predicted by eq (1) for pin ended conditions (even in the case of double curvature), wall strength was overestimated when it was assumed that flat ended walls similar to those in this investigation are fixed ended. Assumptions made with respect to end conditions are discussed in the following section.

(2) Stiffness: The stiffness $E I$, in the case of masonry, is subject to change with the magnitude and distribution of stresses that act on the cross section. Both $E$ and $I$ depend on the moment distribution at failure; $E$ decreases with increasing stresses, as can be seen in curve $\mathrm{A}$ in figure 6.1 while $I$ decreases with section cracking. Since greater deflections and smaller failure loads are associated with greater eccentricities and slenderness, more section cracking takes place with a corresponding decrease in stiffness. It has been shown for concrete columns [9] that slenderness effects can be approximately predicted by using an "equivalent $E I "$ :

$$
E I=\frac{E_{i} I_{n}}{2.5}
$$

where

$E_{i}=$ Initial tangent modulus of elasticity,

$I_{n}=$ Moment of inertia of section based on uncracked net section. 
However. this equation is valid only in a range of loads and eccentricities where section cracking is not very significant.

For the case of brick masonry, slenderness effects have been approximately predicted [8] by the following equation:

$$
E I \simeq E_{i} I_{n}\left(0.2+\frac{P}{P_{0}}\right) \leqslant 0.7 E_{i} I_{n}
$$

where $P_{o}=$ Short wall axial load capacity determined on the basis of prism strength, or for low vertical loads:

$$
E I=\frac{E_{i} I_{n}}{3}
$$

In the interpretation of test results of this investigation eq (3) was used for the reinforced walls. assuming that reinforced masonry and reinforced concrete have similar properties. For unreinforced walls the reduction was based on the observation that the initial tangent modulus of elasticity equals about 3.5 times the modulus of elasticity at failure. Thus the "equivalent $E I$ " was taken as:

$$
E I=\frac{E_{i} I_{n}}{3.5}
$$

\subsubsection{6-in Reinforced Walls}

(1) End fixity: End conditions are related to the shape of deflection curves. Figure 6.8 shows measured deflection curves for the 10-, 16-, and $20-\mathrm{ft}$ reinforced walls. The curves for the 10 -ft walls seem to indicate that there was only a minor amount of end fixity in spite of the flat-ended condition. The
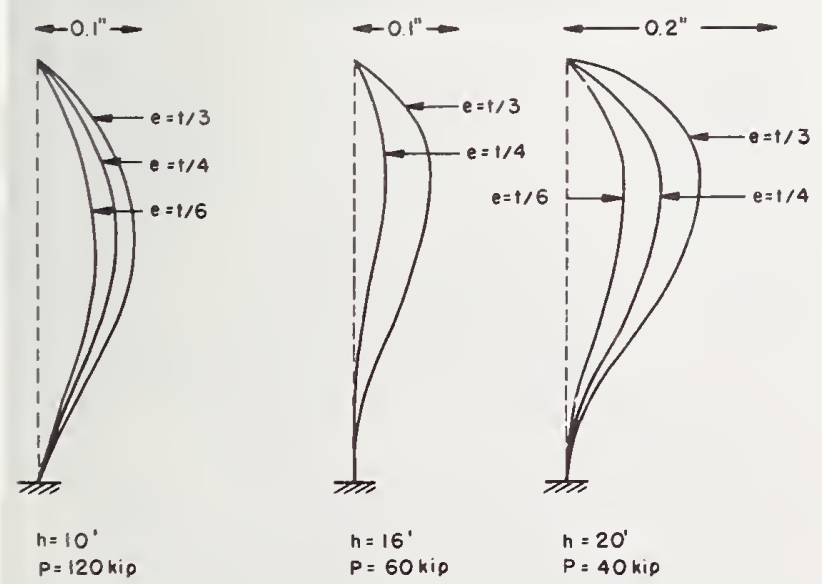

FIGURE 6.8. Typical deflection curves for eccentrically loaded reinforced walls.

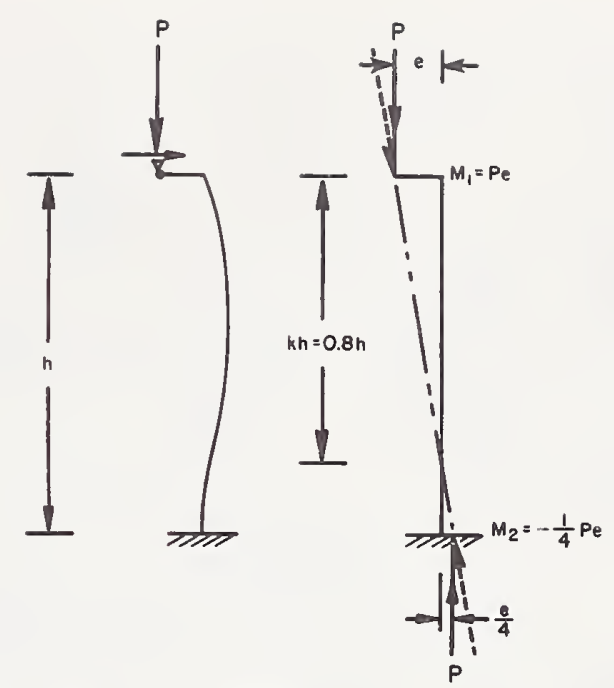

FIGURE 6.9. Assumed conditions of base fixity.

great stiffness of these walls and the relatively minor amount of rotation associated with a significant loss in end stiffness are probably contributing factors to the loss of end fixity. The 16- and 20 -ft walls show a much more pronounced effect of end fixity. Average conditions of base fixity which were assumed for the 16- and 20 -ft walls are illustrated in figure 6.9. These conditions correspond to the following end moments:

$$
\begin{gathered}
M_{1}=P e \quad M_{2}=-1 / 4 P e \\
M_{2} / M_{1}=-1 / 4
\end{gathered}
$$

In accordance with reference [9], this condition would correspond to the following values of $C_{m}$ and $k$ :

$$
\begin{gathered}
C_{m}=0.6+0.4(-1 / 4)=0.5 \\
h=0.8
\end{gathered}
$$

These assumed end conditions are conservative with respect to the 16 - and 20 -ft walls.

(2) Slenderness effects: Figure 6.10 shows the test results of all the reinforced walls. Applied end moments $(P e)$ are plotted against vertical load. It is evident that the strength of the 16 - and $20-\mathrm{ft}$ walls was considerably reduced by slenderness effects.

The solid curve (Curve A) in figure 6.10 is the short-wall interaction curve for the section capacity of these walls, developed on the basis of the average axial strength of the 6 -in prisms which was discussed in section 6.2. As noted previously, this curve is very conservative with respect to moment capacity. From this curve, interaction curves for slender walls can 


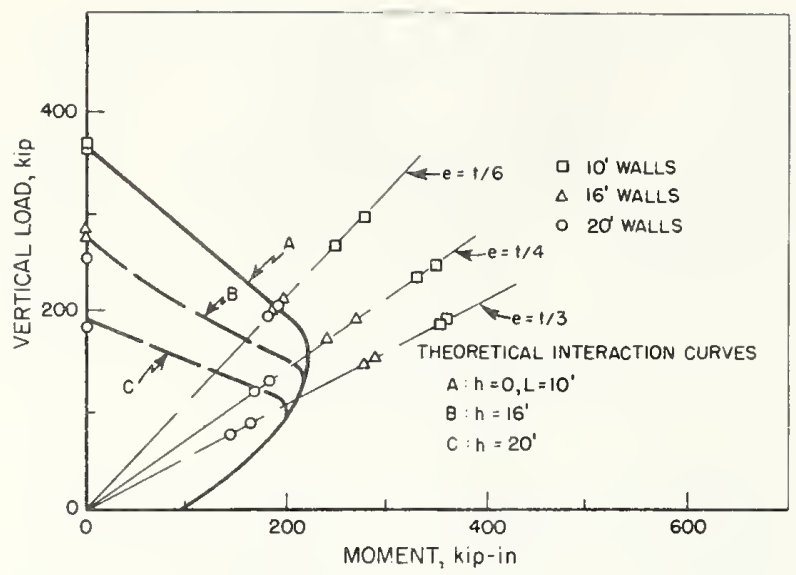

Figtre 6.10. Comparison of test results on 6-in reinforced walls with theoretical interaction curves based on axial prism strength.

be developed by reducing the moment at each level of $P$ by the moment magnifier equation. Such reduced interaction curves were developed, using a $C_{m}$ value of 0.5 , a $k$ value of 0.8 , and an $E I$ value of $E_{i} I_{n} / 2.5$.

For the 10-ft high walls no slenderness effects are predicted by the moment magnifier equation. Thus the solid curve for section capacity is also the interaction curve for the $10-\mathrm{ft}$ walls. Curve $\mathrm{B}$ is the reduced interaction curve for the $16-\mathrm{ft}$ walls. Comparison of this curve with the test results of the $16-\mathrm{ft}$ walls shows that the axial load, which is the critical load for stability-induced compression failures, was accurately predicted. Capacities under eccentric vertical loads are conservatively predicted.

Curve C (fig. 6.10) is the computed interaction curve for the $20-\mathrm{ft}$ walls. This curve closely predicts the axial strength of one of the 20 -ft walls. The other wall developed significantly higher strength. This is probably attributable to the fact that this wall had a longer than average curing period. (This wall was tested at an age of 12-18 days, compared with the 7 13 day age of the lower strength wall.) The two $20-\mathrm{ft}$ walls tested at $t / 6$ eccentricity both developed strength considerably in excess of the predicted strength and developed strengths similar to that of the 16-ft walls. These walls also had a longer than average curing period (19-21 days). At the $t / 4$ eccentricity the predicted strength is close to the observed strength. At the $t / 3$ eccentricity wall strength is overestimated by the theory. At that eccentricity, in accordance with the failure description in table 5.2, the 20 -ft walls developed a stability failure, where very large increments of deflection were associated with relatively minor increase in axial load. These two walls represent an extreme condition $(h / t=41$, $e / t=\frac{1}{3}$ ) which is outside the range presently considered in the design of slender masonry walls. At this extreme condition, wall stiffness $E I$ is considerably reduced by section cracking. The expression $E_{i} I_{n} / 2.5$ is an average stiffness reduction and does not consider the variable of progressive section cracking which is a function of $P / P_{0}$. When this expression was developed it was recognized that it is valid over a range of values of $P / P_{o}$, sufficient to cover all practical design cases. The extreme case of failure at a very low value of $P / P_{o}$ is outside the range of the expression.

It may be concluded that except for the extreme case of $20-\mathrm{ft}$ walls loaded at $t / 3$ eccentricity the theoretical interaction curves are conservative.

It has been noted in section 6.2 that the interaction curve based on axial compressive prism strength is very conservative and that flexural compressive strength increases with increasing strain gradients. The dashed curve shown in figure 6.4 was developed on the basis of the flexural strength at the eccentricity of $t / 3$ and is probably accurate or conservative for eccentricities greater than $t / 3$. Reduced interaction curves, developed from this curve should therefore accurately predict the test results for values of $P$ below the failure load for short walls at the $t / 3$ eccentricity.

Figure 6.11 shows reduced theoretical interaction curves developed from this section capacity curve (curve A), together with the test results. Note that there is excellent correlation between Curve B, the theoretical interaction curve for $16-\mathrm{ft}$ walls, and the test results. The solid portion of curve $B$, as well as the point at axial load are computed by theory. The

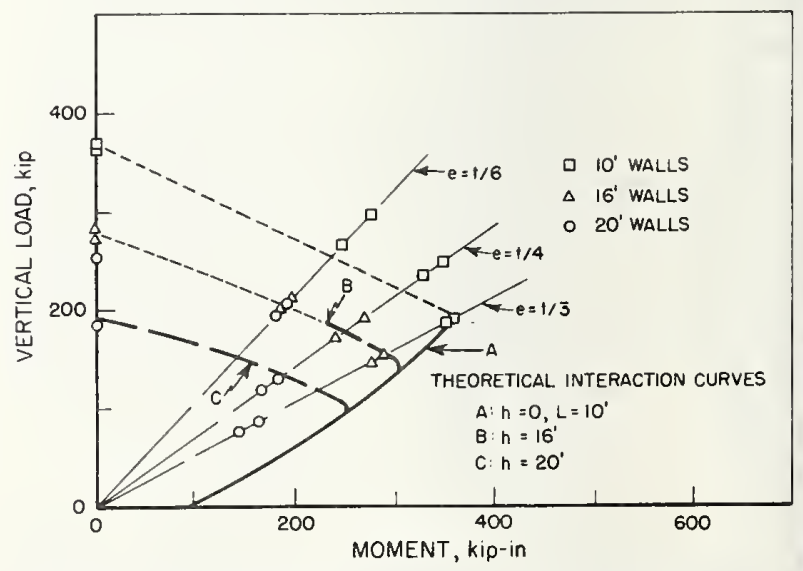

Figure 6.11. Comparison of test results on 6-in reinforced walls with theoretical interaction curves based on flexural compressive strength. 
lighter dashed portion is a straight-line interpolation between the computed axial capacity and the range covered by the solid curve, which is computed. Curve C, which was computed for the 20 - $\mathrm{ft}$ walls shows good correlation with wall tests at the $t / 4$ eccentricity and with one wall test at axial load. The other walls tested at axial load and the walls tested at $t / 6$ eccentricity were stronger and the walls at the t/3 eccentricity failed at a lower load than the predicted load, as previously discussed. On the whole, the trend of the test results, as well as actual failure loads are in good agreement with the theoretical predictions.

\subsubsection{8-in Unreinforced Walls}

(1) End fixity: Figure 6.12 shows measured deflection curves for the 8-in walls. Again it appears that the 10-ft walls developed only minor end restraint, while 16- and 20-ft walls developed partial end fixity.

The "negative" deflections measured in the $16-\mathrm{ft}$ walls were probably caused by deformation of the aluminum pipes on which the LVDT's were mounted. In all other tests larger diameter pipe was used. Again it is assumed that base-fixity conditions were in accordance with figure 6.9.

(2) Slenderness effects: Test results of the 8-in wall panels are plotted in figure 6.13. Under axial load the two 20 -ft walls and the two $16-\mathrm{ft}$ walls failed at different load levels, and the average failure load of the $16-\mathrm{ft}$ walls was considerably higher than that of the $20-\mathrm{ft}$ walls. The $10-\mathrm{ft}$ walls, however, showed a considerable discrepancy in failure load. One of these walls developed a failure load close to that of the $16-\mathrm{ft}$ walls, and the other failed at a lower load.

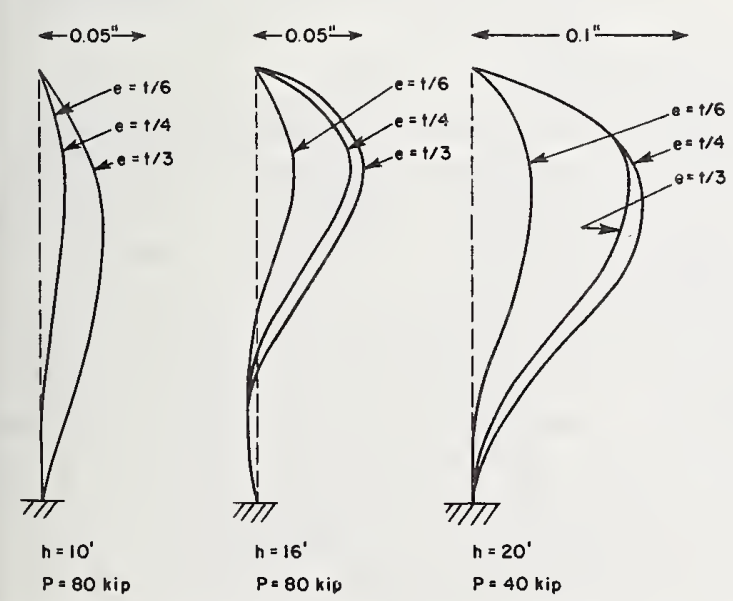

Figure 6.12. Typical deflection curves for eccentrically load unreinforced walls.
Two of the prisms failed at loads similar to the failure loads of the $16-\mathrm{ft}$ walls and one prism developed greater strength than all other specimens. There appears to be a polarization of test results of the 16- and the $20-\mathrm{ft}$ walls. The strength of the $10-\mathrm{ft}$ walls and the prism strengths are such that no statistically significant effect of wall height on strength can be derived for walls up to the height of $16 \mathrm{ft}$.

At the $t / 6$ eccentricity all the wall and prism tests except for one $10-\mathrm{ft}$ wall test are concentrated between the failure loads of 166 to $200 \mathrm{kip}$. There appears to be no noticeable correlation between wall height and strength within the range of wall heights tested.

At the $t / 4$ and $t / 3$ eccentricities there is a definite polarization in accordance with wall heights. However, this observation is not supported by the prism strengths. At the $t / 4$ eccentricity prism tests have an average similar to the average of all wall tests, and at the $t / 3$ eccentricity there is a considerable variation in prism strength with a scatter over the entire range of wall strengths. Since at the maximum eccentricity any test will be close to the failure envelope of the section capacity, test results may be very sensitive to the precision of the positioning of applied loads. The possibility therefore, can not be ruled out that the polarization of these test results may be coincidental and that the spread of the results may represent normal strength variations due to material strength, workmanship and precision of load application.

The solid curve in figure 6.13 (Curve A) is the short-wall interaction curve developed on the basis of the average axial strength of the 8 -in prisms. This curve was discussed in section 6.2 and it was con-

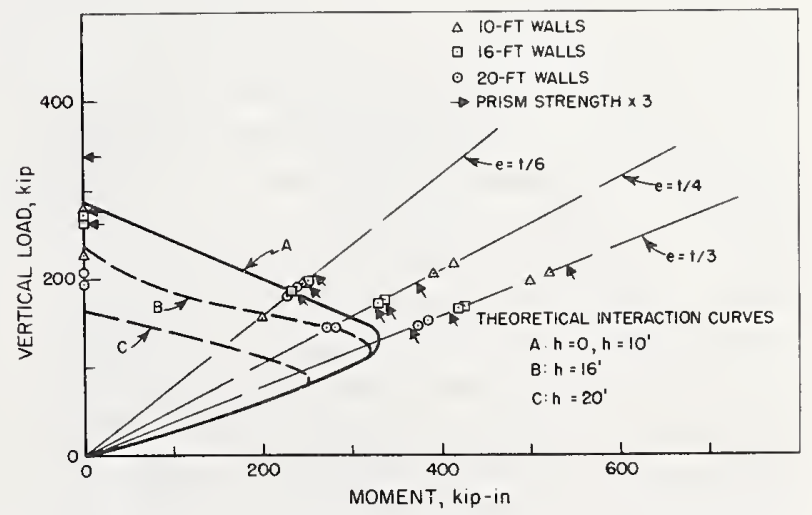

FiguRE 6.13. Comparison of test results on 8-in unreinforced walls with theoretical interaction curves based on axial prism strength. 


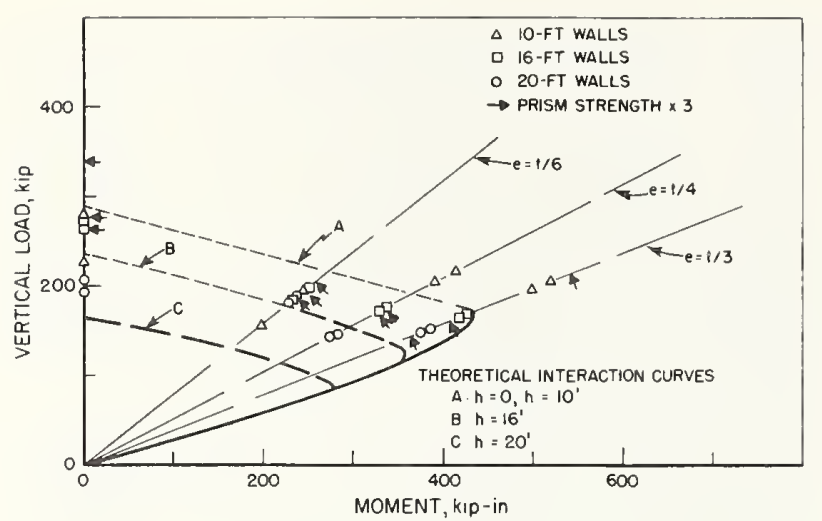

FIGURE 6.14. Comparison of test results on 8-in unreinforced walls with theoretical interoction curves based on flexural compressive strength.

cluded that, in general, this curve is conservative with respect to eccentric loads. Curves B and C are reduced interaction curves for the 16 - and $20-\mathrm{ft}$ walls, respectively. These curves were developed from Curve A by the moment magnifier method, using the stiffness reduction derived for unreinforced masonry: $E I=E_{i} I_{n} / 3.5$. In accordance with the assumed end conditions, a $C_{m}$ factor of 0.5 was used, together with a $k$ factor of 0.8 . Note that, in all cases, these reduced interaction curves are conservative.

Figure 6.14 shows reduced interaction curves which were developed from a short-wall interaction curve that is based on the average prism strength at the $t / 3$ eccentricity $\left(f^{\prime}{ }_{m}=2,320 \mathrm{psi}\right)$. As previously noted, this curve is probably accurate or slightly conservative for eccentricities greater than $t / 3$. These reduced interaction curves should be less conservative than the curves shown in figure 6.13 and should predict the ultimate strength of the walls more closely. In figure 6.14, Curve $\mathrm{A}$ is the short-wall interaction curve, Curve B is for $16-\mathrm{ft}$ walls and Curve $\mathrm{C}$ is for 20 -ft walls. The solid portions of these curves were computed by theory. The lighter dashed lines are straight-line interpolations between the end point of the computed curves and the computed axial loads. The reduced curves, thus computed, are slightly conservative. This may be because of the fact that at the $t / 3$ eccentricity $10-\mathrm{ft}$ wall strength exceeded the average prism strength. At the $t / 3$ and $t / 4$ eccentricities, the order of magnitude of observed slenderness effects is in good agreement with the magnitude of computed slenderness effects. This agreement also occurs with respect to the 16- and 20 -ft walls under axial loads. In all these cases the reduced interaction curves are conservative. At the $t / 6$ eccentricity the wall tests show no correlation between length and ultimate load, however, the reduced curves are conservative with respect to the 16- and 20 -ft walls.

It may be concluded from the discussion of figures 6.13 and 6.14 , that the strength of slender walls was conservatively predicted by the moment magnifier method, when it was assumed that the flexural compressive strength of the masonry equals the average axial prism strength. The order of magnitude of slenderness effect, as well as the strength of slender walls were approximately predicted by the momeni magnifier method, when the flexural compressive strength of masonry at load eccentricities greater than $t / 3$ was assumed to equal the average flexural strength of prisms, loaded at a $t / 3$ eccentricity.

\section{Discussion of Present Design Procedures}

The latest recommended design procedures for eccentrically loaded slender concrete masonry walls are presented in the 1968 NCMA standard [2]. This standard requires that members subject to eccentric loads be proportioned such that:

$$
\frac{f_{a}}{F_{a}}+\frac{f_{m}}{F_{m}} \leqslant 1
$$

where:

$f_{a}=$ Computed axial compressive stress equal to the total vertical load divided by the net area,

$F_{a}=$ Compressive stress permitted by the standard for axial loading,

$f_{m}=$ Computed flexural stress,

$F_{m}=$ Flexural compressive stress permitted by the standard.

The allowable compressive stress under axial loading is reduced for slenderness effects, using a reduction factor of $\left[1-(h / 40 t)^{3}\right]$. The allowable short-wall axial stress is $0.2 f^{\prime} m$ for unreinforced masonry and $0.225 f^{\prime} m$ for reinforced masonry. Allowable flexural compressive stresses are $0.3 f^{\prime}{ }_{m}$ and $0.33 f^{\prime} m$ for unreinforced and reinforced masonry, respectively. The standard does not permit tensile stresses in unreinforced masonry walls built with hollow units, thus limiting load eccentricity to the edge of the kern. For solid unreinforced masonry and for reinforced masonry cracked sections are permitted. It is also stated in the standard, that up to a load eccentricity of $t / 3$, reinforced walls may be designed on the basis of an uncracked section. 
These design recommendations consider wall slenderness; however, the $h / t$ ratio does not take into account the properties of the cross section, and therefore does not differentiate between solid and hollow sections. Other variables associated with slenderness effects and not considered in these design equations are end fixity effects (effective length), ${ }^{3}$ the effect of the manner in which the member is loaded (the shape of the moment diagram and the resultant deflection curve), and the relationship between the strength and the modulus of elasticity of the masonry.

A short-wall interaction curve can be developed using the recommended interaction equation, eq (5), the allowable axial and flexural stresses, and the other requirements contained in the NCMA standard as mentioned previously.

Figure 7.1 shows interaction curves of allowable vertical loads and moments, computed for the 6-in reinforced masonry walls by the NCMA standard. Masonry strength $f^{\prime} m$ was taken as the average axial compressive strength of the 6-in three-block prisms tested in the investigation reported herein. The dashed curve (A) was computed without any slenderness reduction and represents short-wall capacity. The solid curves labeled B and C were computed for the 10- and 16-ft walls, respectively. The dashed radial lines represent the load cccentricities used in the tests. The intersection points of these radial lines with the interaction curves represent the allowable vertical loads at these eccentricities. Note that the upper, linear part of the interaction curves, which represents capacities of uncracked sections, is extended in each case by a dotted line to the $t / 3$

${ }^{3}$ Some general consideration is given in NCMA Standard to cantilever members and members subject to sidesway.

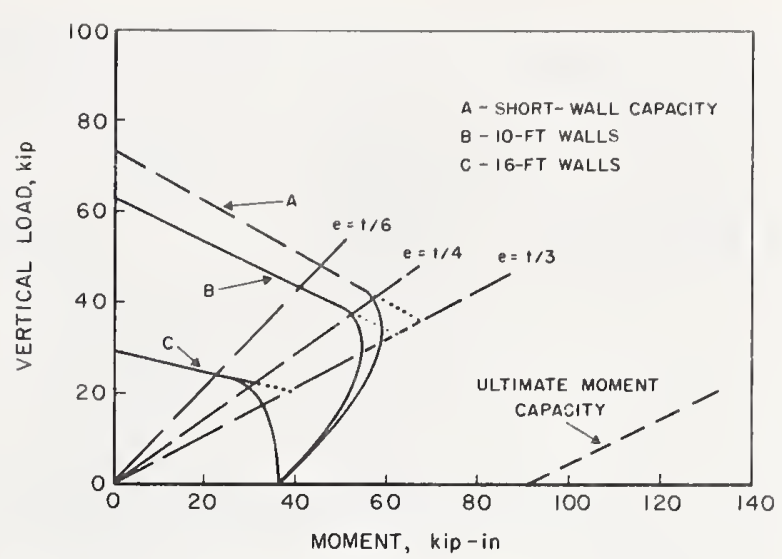

FIGURE 7.1. Allowable loads on 6-in reinforced walls (NCMA, 1968).

eccentricity. These dotted lines correspond to the provision that walls may be designed for uncracked sections up to the $t / 3$ eccentricity. Curve $\mathrm{C}$, which corresponds to an $i / t$ ratio of 34 , is actually an extrapolation of the NCMA standard which limits the $h / t$ ratio for load bearing reinforced walls to 30 . The NCMA equation could not be used to develop an interaction curve for the 20 - $\mathrm{ft}$ walls, since the equation for slenderness reduction goes to 0 at an $h / t$ ratio of 40.

Computed allowable loads for the 6-in reinforced walls and average ultimate strengths of the test specimens are compared in table 7.1. Margins of safety were computed in two ways: The ratio of average ultimate loads to allowable loads was computed for specific load eccentricities, and the ratio of ultimate moments to allowable moments was computed for specific levels of vertical loads.

The first case pertaining to a constant load eccentricity involves a radial "scaling down" of the ulti-

TABLE 7.1 Comparison of Allowable Loads by NCMA Standard with Average Ultimate Load Capacities of 6-in Reinforced Walls

\begin{tabular}{|c|c|c|c|c|c|c|c|}
\hline \multirow[b]{2}{*}{ Wall Length } & \multirow[b]{2}{*}{$e / t$} & \multicolumn{3}{|c|}{ Case I } & \multicolumn{3}{|c|}{ Case 2} \\
\hline & & $\begin{array}{l}\text { Allowable } \\
\text { Vertical } \\
\text { Load } \\
\text { kip }\end{array}$ & $\begin{array}{l}\text { Average } \\
\text { Ultimate } \\
\text { Vertical Load } \\
\text { Capacity } \\
\text { kip }\end{array}$ & $\begin{array}{c}\text { Margin of } \\
\text { Safety } \\
\left(\frac{\text { Ultimate Load }}{\text { Allowable Load }}\right)\end{array}$ & $\begin{array}{l}\text { Allowable } \\
\text { Moment } \\
\text { kip-in }\end{array}$ & $\begin{array}{c}\text { Computed Ul timate } \\
\text { Moment at } \\
\text { Allowable } \\
\text { Vertical Load } \\
\text { kip-in }\end{array}$ & $\begin{array}{c}\text { Margin of } \\
\text { Safety } \\
\left(\begin{array}{l}\text { Ultimate Moment. } \\
\text { Allowable Moment) }\end{array}\right.\end{array}$ \\
\hline 10 & $\begin{array}{l}0 \\
1 / 6 \\
1 / 4 \\
1 / 3\end{array}$ & $\begin{array}{c}63 \\
43 \\
38 \\
29(33) \text { al }\end{array}$ & $\begin{array}{l}365 \\
280 \\
242 \\
188\end{array}$ & $\begin{aligned} & 5.8 \\
& 6.5 \\
& 6.4 \\
& 6.5(5.7)\end{aligned}$ & $\begin{array}{c}0 \\
40 \\
52 \\
54(62)\end{array}$ & $\begin{array}{l}210 \\
175 \\
165 \\
148\end{array}$ & $\begin{array}{c}4^{\infty} \\
3.4 \\
2.7(2.4)\end{array}$ \\
\hline 16 & $\begin{array}{l}0 \\
1 / 6 \\
1 / 4 \\
1 / 3\end{array}$ & $\begin{array}{c}28 \\
24 \\
21(22) \\
18(20)\end{array}$ & $\begin{array}{l}278 \\
207 \\
181 \\
150\end{array}$ & $\begin{array}{r}9.9 \\
8.6 \\
8.6 \\
8.3(7.5)\end{array}$ & $\begin{array}{c}0 \\
23 \\
30 \\
34(38)\end{array}$ & $\begin{array}{l}147 \\
140 \\
135 \\
129\end{array}$ & $\begin{array}{c}6.1 \\
4.5 \\
3.8(3.4)\end{array}$ \\
\hline
\end{tabular}

af Numbers in parentheses are computed on the basis of an uncracked section. 
mate interaction diagram along the lines of constant eccentricity. This scaling down indicates the margins of safety against an increase in vertical loads, acting at the same eccentricity. In a building, a load increase without a change in eccentricity would correspond approximately to an increase in occupancy load above the design load level. The margins of safety for this case are given in table 7.1. For the 10 $\mathrm{ft}$ walls they vary from 5.7 to 6.5 . For the $16-\mathrm{ft}$ walls the margins of the safety vary from 7.5 to 9.9. It appears that these margins of safety are quite high for short walls, and, for the end conditions applied in this investigation, they increase for increasing wall slenderness.

The second case, which pertains to a constant vertical load, while increasing the moment acting on the wall, corresponds to a horizontal scaling down of the ultimate interaction diagram. In a building, this case of constant vertical load would correspond to an increase in horizontal live loads (wind loads) without a corresponding increase in vertical live loads. The margins of safety for this second case are also presented in table 7.1. It is important to note, that within the limit of vertical loads presently permitted in design, ultimate moments increase with vertical loads. At the maximum permitted vertical load, at which no moment is permitted in the NCMA standard, the walls can actually support a greater ultimate moment than at any lower vertical load. For eccentric loads the margins of safety vary from 2.4 to 4.4 for the $10-\mathrm{ft}$ walls and from 3.4 to 6.1 for the 16 - $\mathrm{ft}$ walls. It is apparent that the safety margins decrease with increasing load eccentricity. It can also be observed that the safety margins are greater for the more slender walls.

The ultimate moment capacity is shown by a dashed line in figure 7.1. It appears that much of the margin of safety is due to the high ultimate moment at no vertical load which is attributable to the reinforcement. Since the specimens in this investigation had about twice the minimum required reinforcement, it may be concluded that for walls with minimum reinforcement, margins of safety may have been smaller. When margins of safety for Case 1 are compared with those given for Case 2 , it is apparent that for eccentricities greater than $t / 6$, and particularly for large eccentricities, the margin of safety against an increase in horizontal live loads is substantially smaller than that provided against an increase in vertical live loads. Thus, it may be concluded that reinforced walls, designed in accordance with present practice have a greater and more uniform margin of safety with respect to vertical live loads than the margin provided with respect to horizontal live loads.

Figure 7.2 shows interaction diagrams for allowable vertical loads and moments, computed by the

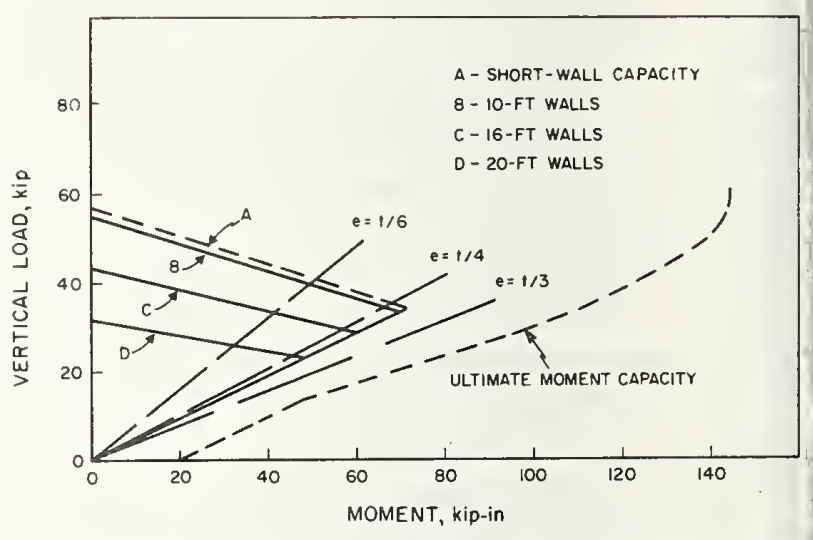

Figure 7.2. Allowable loads on 8-in unreinforced walls (NCMA, 1968).

NCMA standard for the 8-in unreinforced masonry walls. Curve $A$ is the short-wall interaction curve, and curves B, C, and D are for the 10-, 16- and the 20 -ft walls, respectively. Note that the interaction curves are cut off at the kern eccentricity, which is slightly larger than the $t / 4$ eccentricity. Thus the $t / 3$ eccentricity falls outside the curves, since it is not permitted under this standard. The dashed line to the right of the curves is the computed short-wall ultimate moment capacity which was based on the flexural compressive prism strength at the $t / 3$ eccentricity. Curves C and D are extrapolations of the NCMA standard, which limits the maximum $h / t$ ratio to 20 for unreinforced load-bearing walls.

Computed allowable loads for the 8-in unreinforced walls are compared in table 7.2 with the average ultimate strengths achieved by the test specimens. Margins of the safety against an increase in vertical loads applied at the same eccentricity (Case 1), vary from 4.4 to 6.4 for the 10 -ft walls, from 5.8 to 6.2 for the 16 -ft walls, and from 6.0 to 7.1 for the $20-\mathrm{ft}$ walls. In general it appears, for the particular end and loading conditions used in this investigation, that these margins of safety are quite uniform and on the high side.

Safety margins against an increase in moments at the same vertical load (Case 2 ) are also given in table 7.2. As in the case of the 6 -in reinforced walls, these margins of safety decrease with increasing eccentricity, dropping to 1.75 at the $t / 3$ eccentricity. It is 
TABLE 7.2 Comparison of Allowable Loads by NCMA Standard with Average U1timate Load Capacities of 8-in Unreinforced Walls

\begin{tabular}{|c|c|c|c|c|c|c|c|}
\hline \multirow[b]{2}{*}{ Wall Length } & \multirow[b]{2}{*}{$e / t$} & \multicolumn{3}{|c|}{ Case 1} & \multicolumn{3}{|c|}{ Case 2} \\
\hline & & $\begin{array}{l}\text { Allowable } \\
\text { Vertical } \\
\text { Load } \\
\text { kip }\end{array}$ & $\begin{array}{l}\text { Average } \\
\text { U1timate } \\
\text { Vertical Load } \\
\text { Capacity } \\
\text { kip }\end{array}$ & $\begin{array}{c}\text { Margin of } \\
\text { Safety } \\
\left(\begin{array}{c}\text { U1timate Load } \\
\text { Allowable Load }\end{array}\right)\end{array}$ & $\begin{array}{l}\text { Al lowable } \\
\text { Moment } \\
\text { kip-in }\end{array}$ & $\begin{array}{c}\text { Computed Ultimate } \\
\text { Moment at } \\
\text { Allowable } \\
\text { Vertical Load } \\
\text { kip-in }\end{array}$ & $\begin{array}{c}\text { Margin of } \\
\text { Safety } \\
\left(\begin{array}{c}\text { U1timate Moment } \\
\text { ATlowable Moment }\end{array}\right)\end{array}$ \\
\hline 10 & $\begin{array}{c}0 \\
7 / 6 \\
1 / 4 \\
\end{array}$ & $\begin{array}{l}57 \\
39 \\
33 \\
\end{array}$ & $\begin{array}{l}252 \\
177 \\
210 \\
\end{array}$ & $\begin{array}{l}4.4 \\
4.5 \\
6.4 \\
\end{array}$ & $\begin{array}{r}0 \\
50 \\
63\end{array}$ & $\begin{array}{l}144 \\
122 \\
110\end{array}$ & $\begin{array}{l}{ }^{\infty} .4 \\
1.75\end{array}$ \\
\hline 16 & $\begin{array}{c}0 \\
1 / 6 \\
1 / 4\end{array}$ & $\begin{array}{l}43 \\
33 \\
30\end{array}$ & $\begin{array}{l}268 \\
197 \\
174\end{array}$ & $\begin{array}{l}6.2 \\
5.8 \\
5.8\end{array}$ & $\begin{array}{r}0 \\
42 \\
57\end{array}$ & $\begin{array}{l}129 \\
108 \\
100\end{array}$ & $\begin{array}{l}\infty \\
2.6 \\
1.75\end{array}$ \\
\hline 20 & $\begin{array}{c}0 \\
1 / 6 \\
1 / 4\end{array}$ & $\begin{array}{l}32 \\
26 \\
24\end{array}$ & $\begin{array}{l}202 \\
184 \\
143\end{array}$ & $\begin{array}{l}6.3 \\
7.1 \\
6.0\end{array}$ & $\begin{array}{r}0 \\
33 \\
46\end{array}$ & $\begin{array}{r}105 \\
88 \\
80\end{array}$ & $\begin{array}{l}\infty \\
2.7 \\
1.75\end{array}$ \\
\hline
\end{tabular}

-important to note. that for unreinforced walls built of solid units, which can be designed on the basis of a cracked section, these margins of safety may drop even lower and approach unity. Thus, while margins of safety against an increase of vertical loads are rather high. the margins against an increase in horizontal loads may be extremely small.

The allowable vertical loads and moments shown in figures 7.1 and 7.2 and listed in tables 7.1 and 7.2 were based on the average axial compressive strengths of the prisms as determined by tests. For the 6-in prisms. $f^{\prime}{ }_{m}$ was 1890 psi and for the 8-in prisms, $f^{\prime}{ }_{m}$ was 1700 psi. If $f^{\prime}{ }_{m}$ values are not determined by tests, the NCMA standard permits $f^{\prime} m$ values to be assumed on the basis of the unit strengths. For the 6-in and 8-in hollow concrete block used in this investigation which had strengths of $4080 \mathrm{psi}$ and $4230 \mathrm{psi}$ (net area). respectively, the assumed values of $f^{\prime}{ }_{m}$ permitted are $2017 \mathrm{psi}$ and 2047 psi. Based on this investigation. the assumed values of $f^{\prime}{ }_{m}$ permitted in the NCMA standard are about 7 percent too high for the 6-in prisms and about 20 percent too high for the 8-in prisms. Accordingly, if these assumed values of $f^{\prime}{ }_{m}$ were used in the comparisons given in tables 7.1 and 7.2. the margins of safety would be smaller than the values reported.

Three important conclusions may be drawn from this discussion:

(1) Present NCMA design criteria provide a large margin of safety with respect to vertical loads. This margin of safety is necessary, since present design procedures do not account for all the variables that affect wall capacity.

The most important variables not accounted for are end fixity, the shape of the moment diagram that acts on the wall, cross-sectional characteristics, and the modulus of elasticity of the masonry. In the past, it may not have been justified to account for all these variables, since design standards also contained rather restrictive requirements relating to allowable stresses. lateral support and minimum thicknesses of masonry bearing walls. However, with the increasing use of masonry load-bearing walls in multi-story construction, it is no longer justified to disregard these variables and compensate for the resulting discrepancies by excessive margins of safety.

The close prediction of experimental results in this investigation by the moment magnifier method indicates that the introduction of a rational design method which considers additional variables is practical.

(2) The margin of safety provided by present design practice against an increase in moment, without a corresponding increase in vertical load, is in some cases extremely small. On the other hand. at maximum allowable vertical load, no moment is permitted, although it appears that at that load the wall actually develops the highest ultimate moment capacity. It appears that the philosophy of "radial scaling" which is presently applied to develop allowable wall capacities on the basis of ultimate capacities leads to excessive margins of safety in some cases, while in other cases the margins of safety are extremely slim.

The philosophy behind the scaling down of ultimate loads in order to arrive at reasonable design loads should be reexamined, and all possible load combinations that may act on masonry walls during the life of a building should be taken into account.

(3) Based on the prism strengths obtained in this investigation, the assumed values of axial compres- 
sive strength $f^{\prime}$ m permitted for hollow concrete units in present design criteria are too high and should be reexamined.

\section{Conclusions and Recommendations}

\subsection{Conclusions Related to Tests Results}

The following conclusions can be derived from the interpretation of the test results:

(1) Theoretical interaction curves for the capacity of short concrete masonry walls, computed on the basis of compressive strength developed by masonry prisms under axial loading, closely predict axial compressive load capacity and conservatively predict moment capacity.

(2) Flexural compressive strength of masonry increases with increasing strain gradients (increasing load eccentricity).

(3) Slender concrete masonry wall capacity can be conservatively predicted by the moment magnifier method, when short-wall capacity is based on compressive strength of axially loaded prisms.

(4) The capacity of short and slcnder concrete masonry walls can be predicted with reasonable accuracy when the increase in flexural compressive strength with increasing strain gradients is taken into account.

\subsection{Conclusions Related to Present Design Practice}

The following conclusions can be derived from the review of present design practice:

(1) Present design criteria [2] provide a large margin of safety with respect to vertical loads on load bearing concrete masonry walls but the margin of safety provided against an increase in moment, without an increase in vertical loads, is not uniform and in some cases extremely small.

(2) Introduction of a rational design procedure such as the moment magnifier method which includes additional design variables not presently considered is feasible and also desirable in the interest of both safety and economy.

(3) Assumed values of masonry compressive strength permitted in present design criteria are too high for hollow unit construction.

\section{Acknowledgment}

The contribution of the following persons is acknowledged.

William C. Euler was the Masonry Contractor in charge of the construction of specimens.

James W. Raines was the Laboratory Technician in charge of instrumentation.

Frank A. Rankin and Jessie C. Hairston, Laboratory Technicians, were in charge of the preparation of the specimens for testing.

Henry T. Toennies and Kevin D. Callahan from the National Concrete Masonry Association assisted in the planning of the research program.

Edward O. Pfrang, Chief of the Structures Section, participated in the conception and planning of the program, and made many contributions to this report.

John E. Breen, Professor of Civil Engineering at the University of Texas, critically reviewed the report and participated in the analysis of test results.

\section{References}

[1] National Building Code of Canada, Ottawa, Canada (1965)

[2] National Concrete Masonry Association, Specification for the Design and Construction of Load-Bearing Concrete Masonry, Arlington, Virginia (1968).

[3] Sampling and Testing Concrete Masonry Units, ASTN C140-65T (1965).

[4] Mortar for Unit Masonry, ASTM C270-68 (1968).

[5] Mortar and Grout for Reinforced Masonry, ASTM C476-63 (1963).

[6] Dickey, W. L., Reinforced Brick Masonry, Modern Masonry Conference, Washington, D.C., September 19.20, 1956; Building Research Institute, National Academy of Sciences-National Research Council, Publication 466 (1956).

[7] Deformed Billet-Steel Bars for Concrete Reinforcement, ASTM A615-68 (1968).

[8] Yokel, F. Y., Mathey, R. G., and Dikkers, R. D., Strength of Masonry Walls under Compressive and Transverse Loads. National Bureau of Standards, Building Science Series 34 (in preparation).

[9] MacGregor, J. G., Breen, J. E., and Pfrang, E. O., Design of Slender Concrete Columns, Journal of the American Concrete Institute, Vol. 67, No. 1, pp. 6.28 (1970).

[10] Structural Clay Products Institute, Recommended Practice for Engineered Brick Masonry, McLean, Virginia (1969). 


\section{Announcement of New Publications in Building Science Series}

Superintendent of Documents,

Government Printing Office,

Washington, D. C. 20402

Dear Sir:

Please add my name to the announcement list of new publications to be issued in the series: National Bureau of Standards Building Science Series.

Name

Company

Address

City _._._._. State

Zip Code

(Notification key N-339) 



\section{PERIODICALS}

JOURNAL OF RESEARCH reports National Bureau of Standards research and developinent in physics, mathematics, chemistry, and engineering. Comprehensive scientific papers give complete details of the work, including laboratory data, experimental procedures, and theoretical and mathematical analyses. Illustrated with photographs, drawings, and charts.

Published in three sections, available separately:

\section{Physics and Chemistry}

Papers of interest primarily to scientists working in these fields. This section covers a broad range of physical and chemical research, with major emphasis on standards of physical measurement, fundamental constants, and properties of matter. Issued six times a year. Annual subscription: Domestic, $\$ 9.50$; foreign, $\$ 11.75 *$.

\section{Mathematical Sciences}

Studies and compilations designed mainly for the mathematician and theoretical physicist. Topics in mathematical statistics, theory of experiment design, numerical analysis, theoretical physics and chemistry, logical design and programming of computers and computer systems. Short numerical tables. Issued quarterly. Annual subscription: Domestic, $\$ 5.00$; foreign, $\$ 6.25 *$.

\section{Engineering and Instrumentation}

Reporting results of interest chiefly to the engineer and the applied scientist. This section includes many of the new developments in instrumentation resulting from the Bureau's work in physical measurement, data processing, and development of test methods. It will also cover some of the work in acoustics, applied mechanics, building research, and cryogenic engineering. Issued quarterly. Annual subscription: Domestic, $\$ 5.00$; foreign, $\$ 6.25^{*}$.

\section{TECHNICAL NEWS BULLETIN}

The best single source of information concerning the Bureau's research, developmental, cooperative and publication activities, this monthly publication is designed for the industry-oriented individual whose daily work involves intimate contact with science and technology-for engineers, chemists, physicists, research managers, product-development managers, and company executives. Annual subscription: Domestic, $\$ 3.00$; foreign, $\$ 4.00 *$.

- Difference in price is due to extra cost of foreign mailing.

\section{NONPERIODICALS}

Applied Mathematics Series. Mathematical tables, manuals, and studies.

Building Science Series. Research results, test methods, and performance criteria of building materials, components, systems, and structures.

Handbooks. Recommended codes of engineering and industrial practice (including safety codes) developed in cooperation with interested industries, professional organizations, and regulatory bodies.

Special Publications. Proceedings of NBS conferences, bibliographies, annual reports, wall charts, pamphlets, etc.

Monographs. Major contributions to the technical literature on various subjects related to the Bureau's scientific and technical activities.

National Standard Reference Data Series. NSRDS provides quantitive data on the physical and chemical properties of materials, compiled from the world's literature and critically evaluated.

Product Standards. Provide requirements for sizes, types, quality and methods for testing various industrial products. These standards are developed cooperatively with interested Government and industry groups and provide the basis for common understanding of product characteristics for both buyers and sellers. Their use is voluntary.

Technical Notes. This series consists of communications and reports (covering both other agency and NBS-sponsored work) of limited or transitory interest.

Federal Information Processing Standards Publications. This series is the official publication within the Federal Government for information on standards adopted and promulgated under the Public Law 89-306, and Bureau of the Budget Circular A-86 entitled, Standardization of Data Elements and Codes in Data Systems. 


\section{U.S. DEPARTIMENT OF COMMERCE} Washington, D.C. 20230

OFFICIAL BUSINESS

PENALTY FOR PRIVATE USE, \$3OO

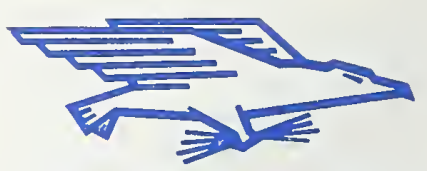

POSTAGE AND FEES PAID U.S. DEPARTMENT OF COMMERCE 